\title{
DESTRUCTION OF THE LITHOSPHERE: FAULT-BLOCK DIVISIBILITY AND ITS TECTONOPHYSICAL REGULARITIES
}

\section{S. I. Sherman}

Institute of the Earth's Crust, Siberian Branch of RAS, Irkutsk, Russia

\begin{abstract}
A new concept is proposed concerning the origin and inception of 'initial' faults and formation of large blocks as a result of cooling of the Archaean lithosphere, during which Benard cells had formed (Fig. 5). At locations where cooling convection currents went down, partial crystallization took place, stresses were localized, and initial fault occurred there. The systems of such fault developed mainly in two directions and gradually formed an initial block pattern of the lithosphere. This pattern is now represented by the largest Archaean faults acting as boundaries of the lithospheric plates and large intraplate blocks (Fig. 6). This group of faults represents the first scale-time level of destruction of the lithosphere. Large blocks of the first (and may be the second) order, which are located on the viscous foundation, interacted with each other under the influence of the sub-lithospheric movements or endogenous sources and thus facilitated the occurrence of high stresses inside the blocks. When the limits of strength characteristics of the block medium were exceeded, the intra-block stresses were released and caused formation of fractures/faults and blocks of various ranks (Fig. 14). This large group, including fault-block structures of various ranks and ages, comprises the second level of the scale-time destruction of the lithosphere.

The intense evolution of ensembles of faults and blocks of the second scale-time level is facilitated by short-term activation of fault-block structures of the lithosphere under the influence of strain waves. Periods of intensive short-term activation are reliably detected by seismic monitoring over the past fifty years. Investigations of periodical processes specified in the geological records over the post-Proterozoic periods [Khain, Khalilov, 2009] suggest that in so far uninvestigated historical and more ancient times, the top of the lithosphere was subject to wave processes that influenced the metastable state of the fault-block medium of the lithosphere.

At the second scale-time level, the lithosphere is destructed in accordance with the laws of destruction of elastic and brittle bodies; at all hierarchical levels, the lithospheric destruction complies with the similarity patterns; the lithospheric destruction processes are characterized by fractality and take place synchronously with other destruction processes.

Equations of the fault (7) and block divisibility (8) of the lithosphere and the generalized equation (9) of the fault-block divisibility of lithosphere are proposed.

By the present stage of the geodynamic evolution of the Earth, the horizontally-layered zonal pattern of destruction of the Earth has been established (Fig. 15). The next step would be obtaining the knowledge of the law that governs the evolution of the lithospheric destruction as a whole. The subjects for discussions hold be variations of the rheological properties of the vertical profile of the lithosphere, impacts of the time factor on the rheological and mechanical properties, and, lastly, the initial heterogeneity of the lithospheric medium in combination with modern geodynamic processes. This problem is solvable, and its importance for practical applications is undubitable.
\end{abstract}

Key words: lithosphere, destruction, fault, fault-block structure, parameters, Benard Cells.

Recommended by P.V. Makarov 15 November 2012

Citation: Sherman S.I., 2012. Destruction of the lithosphere: Fault-block divisibility and its tectonophysical regularities. Geodynamics \& Tectonophysics 3 (4), 315-344. doi:10.5800/GT-2012-3-4-0077.

\section{ДЕСТРУКЦИЯ ЛИТОСФЕРЫ: РАЗЛОМНО-БЛОКОВАЯ ДЕЛИМОСТЬ И ЕЕ ТЕКТОНОФИЗИЧЕСКИЕ ЗАКОНОМЕРНОСТИ}

\section{С. И. Шерман}


Аннотация: Предложен новый взгляд на происхождение и заложение «первичных» разломов и образование крупных блоков как результат остывания архейской литосферы, во время которого формировались ячеи Бенара (рис. 5). В местах погружения остывающих конвекционных потоков происходила частичная кристаллизация, локализация напряжений и закладывались первичные разломы. Их системы, преимущественно двух направлений, постепенно сформировали первичную блоковую структуру литосферы, которая к настоящему времени представлена самыми крупными разломами архейского заложения, выступающими как ограничения плит и крупных внутриплитных блоков (рис. 6). Эта группа разломов формирует первый масштабно-временной уровень деструкции литосферы. Крупные блоки первого, возможно второго порядков, располагаясь на вязком основании, взаимодействуя друг с другом под влиянием подлитосферных движений или эндогенных источников, способствовали возникновению высоких внутриблоковых напряжений. При превышении пределов прочностных характеристик блоковой среды разрядка внутриблоковых напряжений приводила к формированию разрывов и блоков различных рангов (рис. 14). Эта разноранговая и разновременная по образованию большая группа разломно-блоковых структур формирует второй масштабно-временной уровень деструкции литосферы.

Интенсивному эволюционному развитию ансамблей разломов и блоков второго масштабно-временного уровня способствуют короткопериодные активизации разломно-блоковых структур литосферы, происходящие под воздействием деформационных волн. Интенсивные короткопериодные активизации аргументированно устанавливаются по сейсмическому мониторингу для последних пятидесяти лет. Исследования по периодическим процессам, зафиксированным в геологических летописях за постпротерозойские периоды [Khain, Khalilov, 2009], позволяют считать, что и в пока не изученные исторические и более древние времена для верхней части литосферы были характерны волновые процессы и их воздействие на метастабильное состояние разломно-блоковой среды литосферы.

Деструкция литосферы на втором масштабно-временном уровне происходит в соответствии с законами разрушения упругих и хрупких тел, на всех иерархических уровнях соответствует подобию разрушения, фрактальности процессов деструкции, а также синхронным деструкции другим процессам. Предложены уравнения разломной (7) и блоковой делимости (8) литосферы, а также обобщенное уравнение (9) разломно-блоковой делимости литосферы. К современному геодинамическому этапу развития Земли сформирована горизонтально-слоистая зональная структура деструкции Земли (рис. 15). На очереди - познание закона эволюции деструкции литосферы Земли в целом. Необходимо ввести в обсуждение вариации реологических свойств вертикального разреза литосферы, влияние фактора времени на реологические и прочностные свойства, наконец, первичную неоднородность среды литосферы в сочетании с современными геодинамическими процессами. Проблема решаемая, ее практическая значимость несомненна.

Ключевые слова: литосфера, деструкция, разлом, разломно-блоковая структура, параметры, ячеи Бенара.

\section{1. ВВЕДЕНИЕ}

Длительное напряженное состояние верхней хрупкой части литосферы является главной причиной ее деформации, в большинстве случаев сопровождающейся разломообразованием, которое представляет собой формирование разноранговых разрывов, сочетания которых образуют разломно-блоковые структуры литосферы и ее деструктивные зоны.

Деструкция литосферы - в настоящее время термин широкого пользования. Деструкция - разрушение, нарушение нормальной структуры, целостности литосферы. Геологическими объектами, отражающими про цесс деструкции, являются трещины и разломы различных иерархических уровней и возраста заложения, которые в процессе тектогенеза структурируются в системы и разноранговые (разнопорядковые) блоковые структуры, отражающие общие и частные закономерности деструкции. Более широко рассматривает деструкцию геологических сред П.В. Макаров и др. [Makarov et al., 2007, p. 46], объединяя понятия пластической деформации и разрушения и «рассматривая их как единый процесс эволюции материала под дей- ствием приложенных нагрузок, в ходе которого и образуется иерархия блоков». Действительно, процесс разрушения твердого тела под действием прилагаемых внешних нагрузок происходит в развитии и начинается с локализации напряжений около любой неоднородности в сплошном теле, зарождения микроскопической трещинки и ее развития в дальнейшем в дислокацию и разрывную макроструктуру. Таких неоднородностей может быть много и, следовательно, столько же локальных центров зарождения трещин. Их сложная во времени и пространстве интеграция в единую геологическую структуру - крупный, глубинный или генеральный разлом - происходит прерывисто во времени и в течение длительных временных геологических периодов. Иными словами, развитие разрывов в литосфере Земли происходит эволюционно от мелких к крупным. И действительно, наблюдения и разномасштабные геологические, тектонические и структурнотектонические карты дают полное представление о широком развитии разноранговых разрывов и разломов практически в любом участке земной поверхности.

Классификация разрывов по возрасту заложения и 
размерам (длине, протяженности) проявления позволяет выявить их специфические особенности: длинные разрывы более древние, образуют системы из двух, очень редко трех направлений, расстояния между разрывами в системах большие [Fault Map..., 1977; Suvorov, 1977a, 1977b], что в конечном итоге способствует формированию крупной разломно-блоковой структуры литосферы. В границах крупных блоков выделяются более мелкие блоковые структуры, иногда до нескольких порядков. В других случаях такого дробления не происходит, крупный блок не продолжает «разрушаться» и лишь на срезе коренных обнажений видна трещиноватость горных пород. Практически на континентальной литосфере, где проведено мелко- и среднемасштабное геологическое картирование, не удается выделить «бестрещинные» площади, а в трещиноватых средах всегда констатируется распространение разномасштабных по длине трещин, количественное соотношение которых в координатах «количестводлина» математически значимо проявляется [Sherman, 1977]. Что же лежит в основе того, что физика разрушения твердого тела доказывает эволюционное развитие единичного разрыва от мелкой дислокации к крупной, а сетка разломов, особенно системы крупных разломов, закладывалась в литосфере Земли в различные периоды ее развития, активизировалась неоднократно, но продолжала «сохранять» блоковую структуру литосферы, несмотря на продолжительные эпизоды последующих активизаций и «внутриблокового» дробления? С точки зрения автора, различия в первичном способе нагружения различных объемов масс литосферы и некоторые другие соотношения их параметров определяют сохраняющийся в течение длительных геологических периодов разноранговый ансамбль разломно-блоковых структур литосферы и его воздействие на синхронно протекающие процессы.

Специфика разнорангового блокового ансамбля литосферы Земли заключается в том, что системы блоковой делимости литосферы закладывались на разной генетической основе. Крупнейшие блоки литосферы (континенты и крупные внутриконтинентальные блоки) закладывались первоначально в периоды становления и остывания вязкой литосферы как контуры ячеек Бенара. Их «остаточные» современные формы суть древние, скорее всего архейского заложения, ныне крупные протяженные глубинные, или генеральные, разломы, ограничивающие крупные плиты или границы континентов. В последующие этапы тектогенеза в границах уже заложенных блоков происходило дальнейшее «дробление» литосферы на более мелкие разноранговые блоковые структуры, подчиняясь, в этом случае, законам дробления твердого тела. Разломноблоковая деструкция литосферы с постархейского периода эволюционировала во «встречном» взаимодействии: сначала крупная блоковая делимость высшего масштабно-временного уровня, позже - второго, более низкого, уровня, когда делимость уже заложенных в структуре блоков определялась геодинамическими режимами и другими условиями формирования и дробления среды.

\section{2. РАЗЛОМНО-БЛОКОВАЯ ДЕЛИМОСТЬ ЛИТОСФЕРЫ}

Процесс деструкции твердых геологических формирований обсуждался в ряде публикаций В.В. Пиотровского [Piotrovsky, 1964], М.А. Садовского и др. [Sadovsky et al., 1987], Л.И. Красного [Krasny, 1984], Ю.Я. Ващилова [Vashchilov, 1984], Ю.Г. Гатинского, Д.В. Рундквиста [Gatinsky, Rundquist, 2004; Rundqvist et al., 2004], Т.П. Белоусова и др. [Belousov et al., 1997] Ю.Г. Гатинского и др. [Gatinsky et al., 2008, 2011a, $2011 b$ ] С.В. Гольдина [Goldin, 2002], Г.Г. Кочаряна и А.А. Спивака [Kocharyan, Spivak, 2003], О.В. Петрова [Petrov, 2007], С.И. Шермана [Sherman, 1977, 1996; Sherman, Gladkov, 1999], С.И. Шермана, Нгуен Тронг Ема и К.Ж. Семинского [Sherman et al., 2000], К.Ж. Семинского [Seminsky, 2001; Seminskii, 2008], С.Н. Чернышова, [Chernyshov, 1983] и многих других, в том числе зарубежных авторов [Xu, Deng, 1996; Jin et al., 2007; Zhang et al., 2003; Liu et al., 2007], в числе которых наиболее известна работа Д.Д. Мудди и М.Д. Хилла [Mooddy, Hill, 1960].

Во всех случаях акцентировалось внимание на разных сторонах этого процесса: формировании блоковых структур и их характерных размерах, свойствах пограничных блоковых структур (разломов), интенсивности (плотности) разноранговых разрывов, фиксируемых в определенных зонах и др. Системы разломов, вычленяющие крупные блоки литосферы, можно считать окончательно сформировавшимися к концу протерозоя - к завершению формирования твердой оболочки Земли. Это хорошо показано на «Карте разломов СССР и сопредельных стран» [Fault Map..., 1977], подробная характеристика которой опубликована в книгах, посвященных складчатым и платформенным регионам [Suvorov, 1977a, 1977b]. Разломы и блоки всегда рассматриваются как взаимосвязанные структурные формы, согласно данному Л.И. Красным [Krasny, 1967] определению, что «геоблоками следует называть крупные региональные структуры размером 800-1400×1500 2200 км, т.е. общей площадью около 1-5 млн квадратных километров, обладающие характерными чертами литогенеза, магматизма и метаморфизма и отсюда определенными формационными рядами и соответственно типовым набором минерагенических областей. Ограничениями блоков служат долгоживущие глубинные разломы, характеризующие общую делимость тектоносферы» [Krasny, 1967, p. 117]. Именно ограничения отдельных крупных или небольших массивов литосферы или горных пород глубинными или разломами других рангов и трещинами, хорошо выделяемыми при картировании или дешифрировании, в настоящее время принято называть блоками. Неразрывность по- 
нятий разломов и блоков и их широкое распространение в верхней хрупкой части литосферы дали основание во многих геолого-структурных и геофизических исследованиях структуру литосферы рассматривать как разломно-блоковую [Khain, 1984].

Зональность строения ряда крупных межблоковых и внутриблоковых разломов впервые, пожалуй, описана и оценена К.Ж. Семинским [Seminsky, 2001], предложившим термин «зонно-блоковая структура» литосферы. Детальное изучение зон межблоковых разломов с акцентом на их параметры показало, что поперечные размеры разломных зон значимы по отношению к размерам контактирующих блоков. Подобные наблюдения и послужили основанием считать выявленные количественные соотношения параметров межблоковых разломов не случайными, а сами структуры называть не блоковыми или разломно-блоковыми, а зонно-блоковыми.

Одну из первых мелкомасштабных схем «Геоблокового строения Земли» опубликовал Л.И. Красный [Krasny, 1984], выделив геоблоки кратонные, молодых платформ, геосинклинальных складчатых областей, океанских котловин и морей. В основу классификации блоков была положена принадлежность блоков к определенному типу геологических формаций. Без внимания был оставлен основной критерий выделения блоков как самостоятельных разнопорядковых структур - разломов. Схема Л.И. Красного не получила широкого признания, но смогла отразить принципиальную блоковую структуру земной коры и наметить направление для ее дальнейшего изучения, в том числе на основе количественных методов.

Важной вехой в развитии количественных методов исследования разломов и, как следствие, формируемых ими блоковых структур явились работы М.В. Гзовского [Gzovsky, 1971, 1975], И.И. Чебаненко [Chebanenko, 1963], С.И. Шермана [Sherman, 1977], Ю.Я. Ващилова [Vashchilov, 1984], В.А. Санькова [San'kov, 1989] и ряда других исследователей.

В работе И.И. Чебаненко [Chebanenko, 1963] приведен хороший пример густоты расположения региональных разломов в зависимости от их величины. Массовые закономерности расстояний между разломами позволили И.И. Чебаненко установить следующую эмпирическую зависимость: разломы повторяются через интервалы 12, 25, 37, 50, 100 и 475-500 км. Причина такой делимости в цитируемой работе не объяснена. Тем не менее приведенные цифры во многих случаях определяют и поперечные размеры блоков, формируемые при пересечении систем разломов.

Геометрически правильный рисунок сетки разломов определяется не только выдержанностью направлений систем, но и незначительными колебаниями расстояний между разломами, образующими систему. В монографии С.И. Шермана [Sherman, 1977] было показано, что среднее расстояние между трещинами $M$ в системе определяется их длиной $L$ и оценивается уравнением:

$$
M=k L^{c}
$$

где $k$ и $c$ - эмпирические коэффициенты, численно равные 0.4 и 0.45 соответственно. Физическое объяснение выявленной эмпирической связи можно найти при анализе полей напряжений, образующихся вокруг разломов и уменьшающих общее напряженное состояние среды, которое становится ниже предела прочности горных пород. Такое же физическое обоснование обусловливает области динамического влияния разломов [Sherman et al., 1983]. Уравнение (1) лежит и в основе наиболее вероятной блоковой структуры верхней хрупкой части литосферы, образуемой двумя, реже тремя наиболее развитыми системами разломов. Воспользовавшись установленным уравнением (1), в которое не входит параметр, каким-либо образом отражающий тектоническую активность, можно предопределить примерный план разломной тектоники и использовать его при анализе блоковой тектоники отдельных регионов. Густота же сетки разломов определяется интенсивностью тектонических процессов и контролируется законами разрушения земной коры.

Исследования Ю.Я. Ващилова [Vashchilov, 1984, p. 223] позволили оценить нижние границы блоков. На основе интерпретации гравимагнитных данных им показано, что «...верхние и нижние ограничения блоков совпадают с горизонтальными поверхностями расслоения, определяя тем самым главную форму делимости верхней части Земли; к этим же квазигоризонтальным поверхностям тяготеют глубины заложения разломов и их затухания вблизи верхних ограничений блоков». Время образования блока определяется по возрасту наиболее молодого из разломов, оконтуривающих блок.

Уточнение выводов Ю.Я. Ващилова о глубинах проникновения разломов сделано В.А. Саньковым [San’kov, 1989]. Им предложено уравнение:

$$
H=f(L)
$$

для оценки глубины $H$ проникновения разломов в зависимости от их длины $L$ и показано, что прямая зависимость $H(L)$ применима для верхней части земной коры. С глубиной и переходом длин разломов в класс региональных пропорция связи изменяется с тенденцией уменьшения отношения $H / L$.

На влияние горизонтальных границ раздела на глубины проникновения разломов указывают М.А. Садовский и др. [Sadovsky et al., 1987]. Сопоставляя глубины проникновения разломов с нижними границами блоков коры и литосферы, авторы считают возможным отождествить величину $\mathrm{H}$ с величиной $\mathrm{S}^{0.5}$, где $\mathrm{S}-$ площадь блока. Распределение глубин разделов Н по размерам позволило выделить дискретные распределения преимущественных глубин проникновения раз- 
рывов, образующих ряд: 80, 200, 400, 700 и 3100 км. Характерно то, что среднее значение отношения $\mathrm{H}_{\mathrm{i}+1} / \mathrm{H}_{\mathrm{i}}$ близко к отношению $\mathrm{L}_{\mathrm{i}+1} / \mathrm{L}_{\mathrm{i}}$. Важнейшим выводом работы М.А. Садовского и др. [Sadovsky et al., 1987, p. 91] является утверждение, что «фундаментальное свойство геофизической среды заключается в том, что она состоит из системы неоднородностей (блоков, отдельностей), которые взаимодействуют друг с другом и обмениваются энергией в процессе деформирования среды». И далее обращено внимание на основную особенность блоковой среды - существование иерархического дискретного распределения ее элементов по размерам. Таким образом, в цитируемой работе дано исчерпывающее объяснение подобия разломной и разломно-блоковой сред земной коры и верхней хрупкой части литосферы для широкого диапазона масштабов. Делимость литосферы на блоки и подобие их размеров характеризуются свойствами автомодельности процесса разрушения.

В настоящее время идеи В.В. Пиотровского, Л.И. Красного, М.А. Садовского и мн. др. об иерархичности дискретного ряда блоковых структур получили развитие в книге Г.Г. Кочаряна и А.А. Спивака [Коcharyan, Spivak, 2003], в которой приводится уравнение для оценки линейного размера блоков в зависимости от его иерархического уровня. Обращается внимание на необходимость отчетливо соизмерять масштабы картирования используемого геолого-геофизического материала и ранговые структуры блоков, потенциально на ней выступающие. Разноранговые разломы практически на любом выбранном участке земной поверхности, как правило, представляют собой совокупность решеток разного иерархического уровня. Здесь важно отделить, как пишут авторы цитируемой монографии, «шумовой» фон, который формируют решетки более крупных и более мелких блоков. Принятый подход позволил им выяснить некоторые закономерности разломно-блоковой делимости земной коры, обобщая параметры соизмеримых разноранговых блоков. Заметные отличия в закономерностях деформирования соседних структурных блоков одного ранга подчеркивают роль разграничивающих их разрывов как естественных границ, затрудняющих интенсивность энергообменных процессов. Иными словами, иерархическая делимость среды совпадает с иерархией геодинамических процессов. Цитируемые авторы считают, что «по мере увеличения ранга тектонического нарушения в релаксационном процессе участвуют блоки больших размеров, а релаксация среды может происходить одновременно на нескольких иерархических уровнях» [Kocharyan, Spivak, 2003, p. 412]. Вывод чрезвычайно важен при изучении и анализе сейсмичности в разломно-блоковой среде литосферы. Такое строгое иерархическое классификационное разделение блоков позволило авторам перейти к изучению важнейших геологических структур - межблоковых промежутков (зон разноранговых разломов), их иерархии и соответству- ющих закономерностей, в частности релаксационных процессов - важнейших характеристик реологического разреза литосферы в координатах времени.

Несколько ранее близкий вывод был сделан в работах В.В. Адушкина и др. [Adushkin et al., 1997] и А.А. Спивака и В.Г. Спунгина [Spivak, Spungin, 1998], в которых показано, что режим геодинамических процессов характеризуется ярко выраженной пространственной изменчивостью. Характеристики релаксационных процессов даже для соседних блоков одного ранга могут отличаться, что дает основание использовать параметры релаксационных процессов для сравнительной диагностики территорий по степени долговременной геодинамической устойчивости.

Работами К.Ж. Семинского [Seminsky, 2001, 2003; Seminskii, 2008] выявлено и количественно охарактеризовано 11 уровней иерархии зонно-блоковых структур и установлено, что среднегеометрические соотношения их главных элементов - зон и блоков - в среднем отличаются для смежных порядков в 2.1-2.2 раза. Показано, что наиболее крупные блоки характеризуются поперечными размерами более двух тысяч километров, а ограничивающие их разломы характеризуются как типичные межплитные границы. Для идентификации иерархической подчиненности зонно-блоковых структур рекомендуется использовать параметры зон, так как они меньше всего зависят от неоднородностей субстрата [Seminskii, 2008]. Введенный К.Ж. Семинским [Seminsky, 2001] термин зонно-блоковая структура постепенно входит в «обращение» и чаще используется геологическими группами исследователей, детально изучающих внутреннюю структуру межблоковых разломов. Термин расширяет понятие «область динамического влияния разломов» и уточняет в своем названии их зональное строение, что действительно характерно для крупных межблоковых разломных зон.

Последовательное формирование разноранговой блоковой делимости литосферы понижает ее прочность [Kostyuchenko et al., 2002], существенно снижая квазивязкость. Среда из статической при деформационной нагрузке превращается в динамическую с характерными дополнительными временными характеристиками [Kocharyan, Spivak, 2003]. Именно изменение свойств среды, связанных с ее эволюцией во времени и при вариациях нагрузки, определяет ее структурные перестройки. Сформировавшаяся современная делимость геологической среды является следствием изначальной пространственной неоднородности геодинамических процессов. Как отделить дискретность и подобие разрушения в большом объеме выборок и размеров от разного первоначального условия формирования крупных древних разломов и молодых, участвующих в деструкции? Некогда первично заложенные и картируемые сегодня крупные неоднократно активизированные разломы Земли образуют очень крупные по размерам блоки, но их происхождение 
связано с особым этапом развития литосферы, когда ее реологические свойства из-за повышенных температур и более высокой степени однородности среды определяли иные причины заложения блоковых структур. Известные геолого-структурные параметры разломноблоковой среды литосферы, последовательности образования разноранговых структур, выявляемые при картировании и при экспериментальных лабораторных опытах, дают основание рассматривать деструкцию литосферы как двухуровневый по масштабам и времени развития процесс.

\section{3. ДВУХУРОВНЕВАЯ МАСШТАБНО-ВРЕМЕННАЯ БЛОКОВАЯ ДЕЛИМОСТЬ ЛИТОСФЕРЫ}

Крупные блоки, средние поперечные размеры которых превышают десятки километров и соизмеримы с толщиной литосферы, следует считать первичными, определяющими ее разломно-блоковую структуру или, как минимум, ее верхнюю хрупкую часть. Об этом свидетельствуют исследования нижних границ разломов, ограничивающих блоки, и глубин их проникновения до горизонтальных структурных уровней в литосфере [Vashchilov, 1984]. В более детальном масштабе связь между толщинами осадочных слоев в земной коре и расстоянием между трещинами показали M.В. Рац [Rats, 1962], М.В. Рац и С.Н. Чернышов [Rats, Chernyshov, 1970]. Аналогичная зависимость подтверждается серией физических экспериментов с соблюдением условий подобия, проведенных с различными целями изучения разломообразования в литосфере С.А. Борняковым, К.Ж. Семинским, В.Ю. Буддо с коллегами и детально описанных в монографиях [Seminsky, 2003; Sherman et al., 1983, 1991, 1992, 1994].

Первичные системы разломов, впоследствии образующие блоки, закладываются последовательно одна вслед за другой, что подтверждают экспериментальные данные. При этом любое из избранных направлений формирующегося будущего крупного раздела между блоками закладывается одновременно в нескольких центрах концентрации напряжений, располагающихся по направлению, соответствующему линейной концентрации повышенного напряженного состояния большого массива слоистой среды в целом. Крупный разлом формируется из сочетания, соединения соседствующих сегментов будущего разрыва, практически синхронно развивающихся вдоль одной линии. Сохраняется известное общее представление о физике зарождения единичной дислокации в деформируемой среде на микроуровне, и в то же время мы выходим на мегауровень, сохраняя устоявшиеся геологические представления о формировании крупных разломов литосферы и ее разломно-блоковой структуры. Первичное напряженное состояние литосферы, ее горизонтальная расслоенность с различными физическими свойствами границ разделов и толщин разграничива-

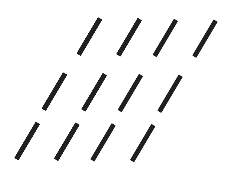

I

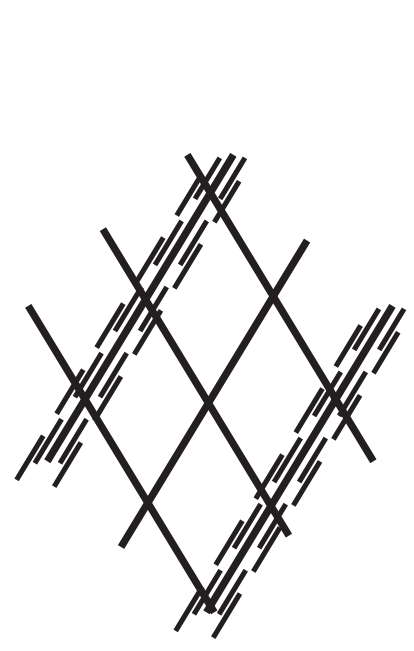

IV

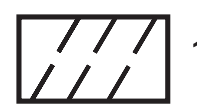

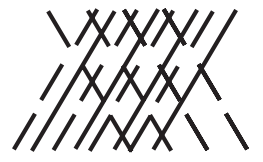

II

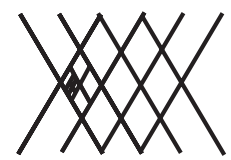

III
Рис. 1. Общие представления о последовательности формирования основных разноранговых систем разломов литосферы в постоянном региональном поле напряжений. I-II - формирование первой и второй систем разломов, $I I I$ - формирования блоков, $I V$ - активизация разломно-блоковых структур, $V$ - формирование разноранговых внутриблоковых разломов и трещиноватости. 1 стадия заложения направления системы разломов в постоянном поле напряжений; 2 - стадия развития одной из систем и заложения новой системы разломов для релаксации локальных напряжений в постоянном региональном поле напряжений; 3 стадии активизации разломов и эволюции внутриблоковой деструкции.

Fig. 1. The general concept of the sequence of formation of main systems of faults in the lithosphere, which vary in ranks, in the constant regional stress field. $I-I I$ - stages of development of first and second fault systems, $I I I$ - formation of blocks, $I V$ - activation of fault-block structures, $V$ - formation of intra-block faults and fractures of various ranks. 1 - the stage of origination of the strike of the fault system in the constant stress field; 2 - the stage of development of one of the systems and origination of a new fault system for release of local stresses in the constant regional stress field; 3 - stages of fault activation and evolution of intra-block destruction.

емых слоев приводят к ранговой разломно-блоковой делимости хрупкой части литосферы от крупных блоков к мелким (рис. 1). В экспериментальных работах при нагружении модели всегда отчетливо фиксируется первичное заложение будущей главной разрывной структуры, в последующем при продолжении нагружения и деформирования подвергающейся все большей и большей степени дробления. При этом никак не ис- 

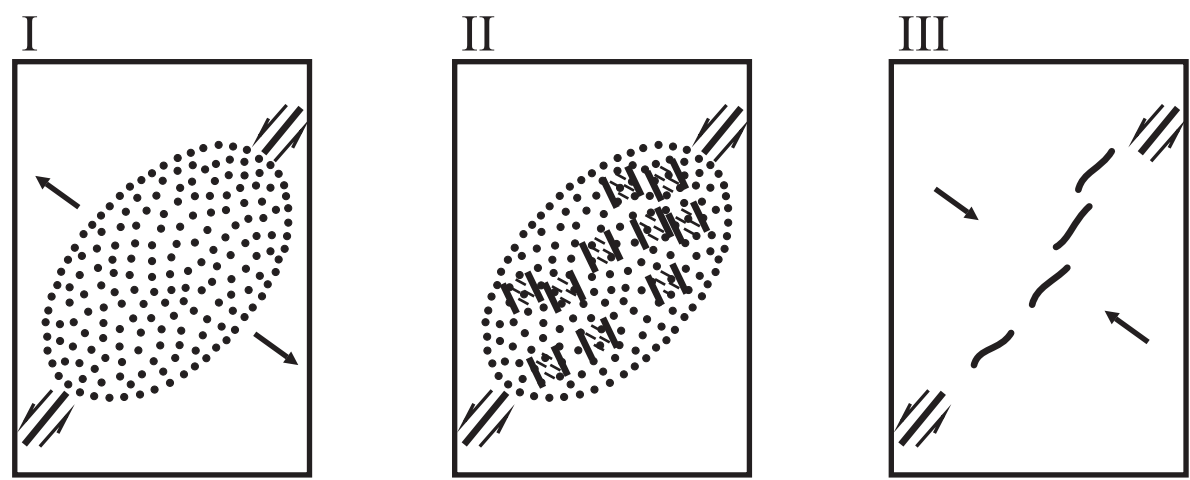

Рис. 2а. Стадии подготовки макроразрыва сдвигового типа [Sobolev, Ponomarev, 2003]. I - постепенное накопление трещин у кончиков концентраторов и их распространение внутрь и по концам микроразрывов; II - укрупнение трещин; III - возникновение эшелона из более крупных трещин, трассирующих будущий макроразрыв.

Fig. 2a. Stages of preparation of a macro-fracture of shear type [Sobolev, Ponomarev, 2003]. I- gradual accumulation of fractures at terminations of concentrators, and their propagation to depth and at terminations of micro-fractures; $I I$ - growth of fractures; $I I I$ - occurrence of larger fractures that are tracing the future macro-fracture.
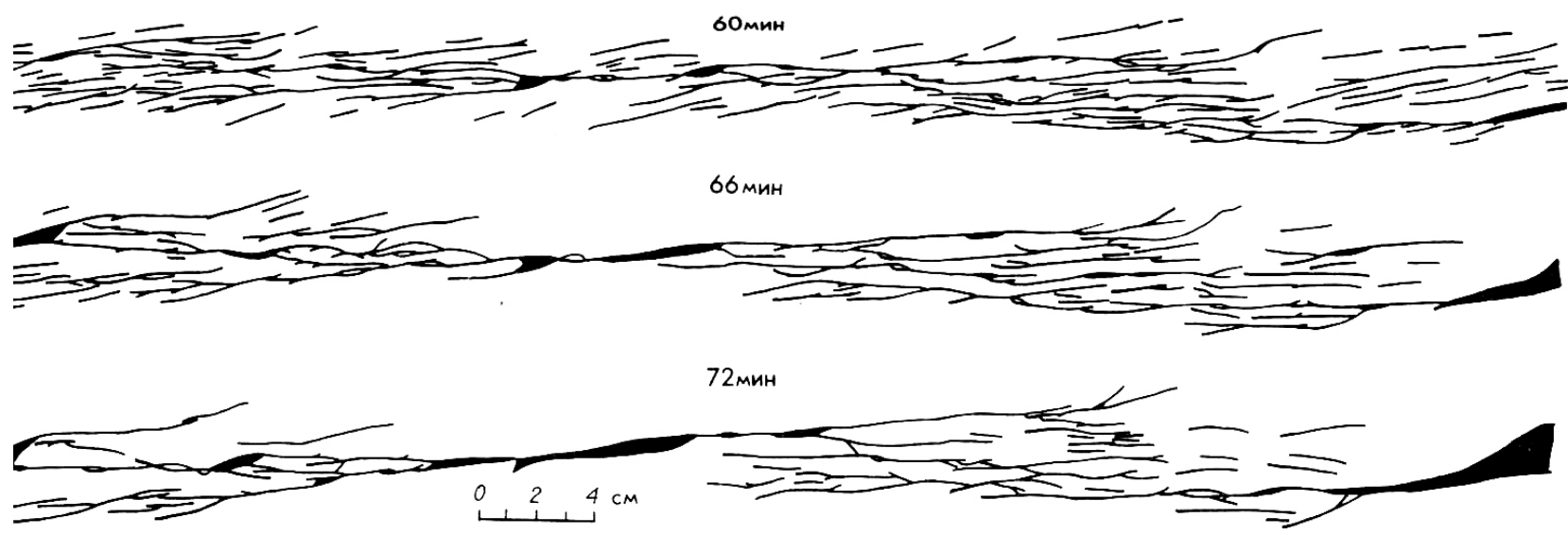

Рис. 2б. Структурные схемы разрывов, соответствующие заключительным этапам формирования сдвиговой зоны в постоянном поле напряжений [Sherman et al., 1991]. Показаны этапы слияния эшелонированных трещин в магистральный разрыв по экспериментальным данным с соблюдением условий подобия: реальное время формирования этапов примерно 1-10 млн лет.

Fig. 2b. Structural diagrams of fractures corresponding to final stages of formation of the shear zone in the constant stress field [Sherman et al., 1991]. Stages are shown as echelon fractures merger to make up the main rupture, according to results of experiments conducted in compliance with conditions of similarity (in reality, the stages may last from 1 to 10 million years).

ключается момент зарождения разрыва из первичных микроскопических сколов (рис. 2а, рис. 2б). Таким образом, заложение систем крупных разломов в значительном по объему природном объекте (литосфере) и начало формирования каждого из конкретных крупных разрывов (инициирование собственно начала разрушения) определяются различными причинами. Возникающие в среде при нагружении или остывании или по другим причинам, например вибрации, напряжения определяют исходный структурный рисунок (форму) и направленность заложения и в последующем развития основных разрывов, ограничивающих в конечном итоге форму «обломков» как результат деформационного процесса (рис. 3). Эта хорошо известная последова- тельность в стадиях разрушения твердых тел, физикоматематическое обоснование которой дано ниже, применима и для понимания процессов в масштабах первичной мегатрещиноватости литосферы Земли.

Сегодня для объяснения первичного формирования крупных разломов Земли и заложения первичной блоковой структуры литосферы можно оттолкнуться от представлений о роли ячей Бенара при формировании диссипативных структур во время кристаллизации вязких сред или из-за воздействия волновых процессов. П.В. Макаров и коллеги о формировании первичных блоков в процессе деформации кристаллической среды пишут: «Фактически блоки - это «замороженные» в кристаллической среде диссипативные структуры, 

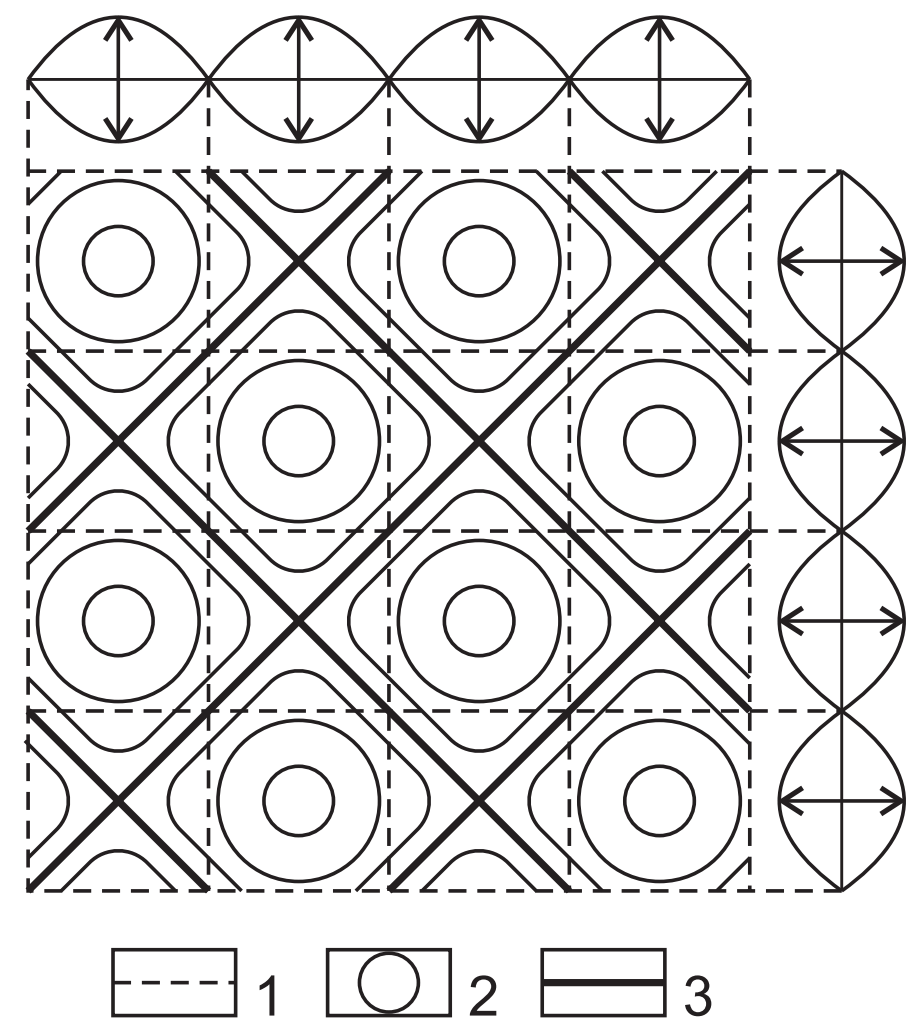

Рис. 3. Схема распределения амплитуд колебаний в результирующих полях, образованных при пересечении двух полей плоских синусоидальных стоячих волн одинаковой частоты и амплитуды колебаний, ориентированных перпендикулярно друг другу [Plotnikov, 1985]. 1 - следы узловых поверхностей составляющих полей; 2 - следы изоамплитудных поверхностей результирующих полей; 3 - результирующие поля.

Fig. 3. The scheme showing the distribution of oscillation amplitudes in the resultant fields formed by the intersection of two fields of plane sinusoidal standing waves of the same frequency and the oscillation amplitude, which are oriented perpendicular to each other [Plotnikov, 1985]. 1 - traces of nodal surfaces of component fields; 2 - traces of iso-amplitude surfaces of resultant fields; 3 - resultant fields.

сформировавшиеся в процессе деформации нагружаемой среды» [Makarov et al., 2007, p. 45]. Генетически блоки предложено рассматривать как ячеи Бенара, но не исчезнувшие после снятия нагрузки, а оказавшиеся замороженными в кристаллической среде из-за колоссальной вязкости упругопластичных сред и весьма продолжительного времени распада. Блочное строение деформируемых твердых тел, по мнению цитируемых авторов, является свидетельством отсутствия принципиальной разницы между хрупкими и пластичными материалами и средами. Из термодинамики известно, что нелинейная нагружаемая среда «ищет» наиболее эффективные механизмы диссипации подводимой к ней энергии. Когда все адаптационные механизмы исчерпаны, среда как целостная структура разрушается. Консолидированные блоки становятся неконсолидированными. Их дальнейшая эволюция, если не обращаться к известным геолого-структурным неоднород- ностям, рассматривается П.В. Макаровым как закономерный физический механизм нарастания масштабов деструкции под углом зрения резонансов в гамильтоновых системах [Makarov, 2007, 2011].

Процессы, происходившие при становлении внешней оболочки Земли и происходящие в ее верхней части, в настоящее время можно отнести к классу открытых неравновесных систем, которые в различных формах взаимодействуют с окружающей средой, в том числе и на уровне энергетических взаимосвязей. При развитии открытых неравновесных систем возникает особого рода структурная упорядоченность. Эти структуры, генерируемые процессами тепломассопереноса во всех сферах, находят особое структурное отражение в верхней оболочке Земли. Их образование связано с диссипативными процессами, развитию которых они способствуют, за что и названы диссипативными [Nicolis, Prigozhin, 1979]. Они же выделены в ряде экспериментальных работ по формированию разломов [Bornyakov, Sherman, 2006; Sherman et al., 2005a, 2005b]. Многочисленные примеры диссипативных структур приводятся в монографии О.В. Петрова [Petrov, 2007]. Более того, автор монографии считает, что «огромная эмпирическая база, характеризующая общность процессов развития разнородных диссипативных структур от атома и галактики до объектов живой природы, дает нам основание предположить фундаментальную роль волновых свойств материи, определяющих ее самоорганизацию» [Petrov, 2007, p. 7]. По автору монографии, наглядным праобразом диссипативных структур являются уже упомянутые ячеи Бенара, которые дают основание рассматривать формирующиеся пространственно-периодические структуры в литосфере как результат изменения ее теплового состояния и роста энтропии. Примерами волновых свойств материи являются ячеистые стоячие внутренние гравитационные волны. Они находят отражение в разноранговых тектонических структурах на земной поверхности. Два из серии примеров, аргументирующих исследования О.В. Петрова [Petrov, 2007], приведены на рис. 4а, 4б. На рис. 4а, 4б показаны новейшие надрегиональные геоблоковые структуры северной полярной области Земли (Сибирская, Восточно-Европейская и Гренландская), которые в тектоническом плане совпадают с одноименными древнейшими платформами. Арктическая платформа представляет собой метаплатформенное образование, включающее в себя остов из отдельных устойчивых древних глыб. Границы структур определяются системой внутриконтинентальных и океанических рифтов, в пределах которых, по данным глубинного сейсмического зондирования, установлено воздымание нижележащих горизонтов мантии, а материковая кора здесь сильно утонена или вовсе отсутствует. В центральных частях этих геоблоков отмечается погружение подошвы земной коры и увеличение ее мощности. На рис. 4б показаны первоначально заложенные структуры Африканского конти- 


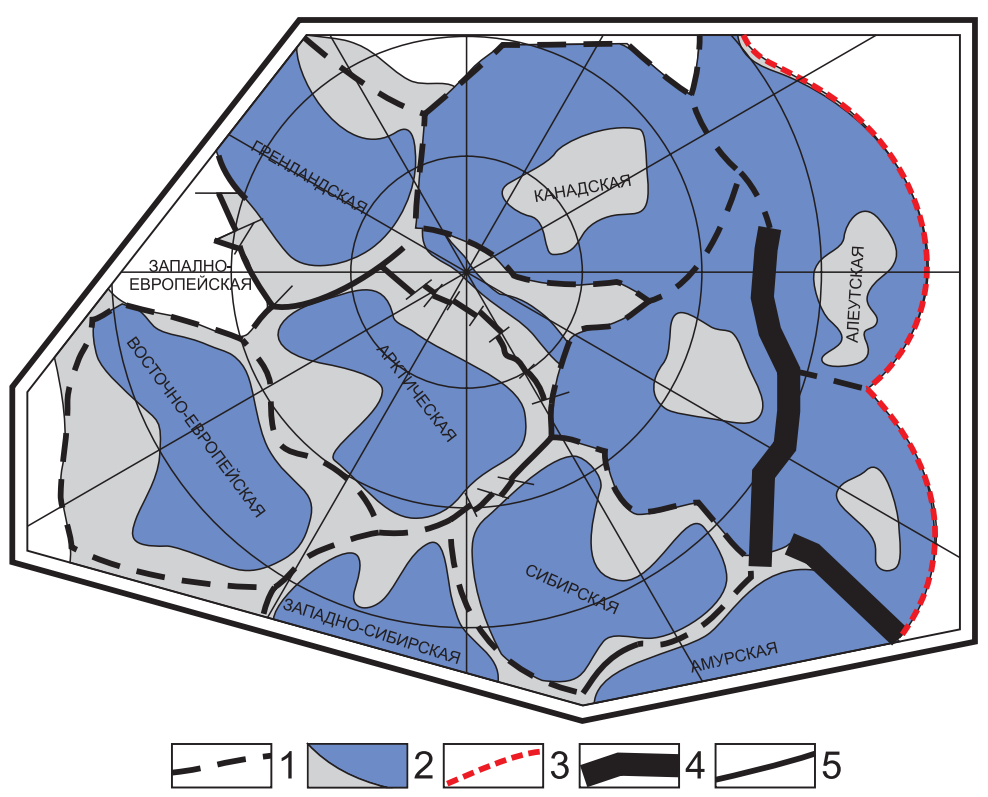

Рис. 4a. Новейшие надрегиональные структуры гравитационной неустойчивости Земли в ее северной полярной области [Рetrov, 2007]. 1 - границы зон спрединга и зон в различной степени проявленного материкового рифтогенеза; 2 - зоны субдукции земной коры; 3 вулканогенные пояса; 4 - всплывающие участки структур гравитационной неустойчивости; 5 - некоторые разрывные нарушения.

Fig. 4a. The recent supra-regional structures of gravitational instability of the Earth in its northern polar region [Petrov, 2007]. 1 - boundaries of spreading zones and zones of variable continental rifting; 2 - crustal zone of subduction; 3 - volcanogenic belts; 4 - emerging parts of structures of gravitational instability; 5 - faults.

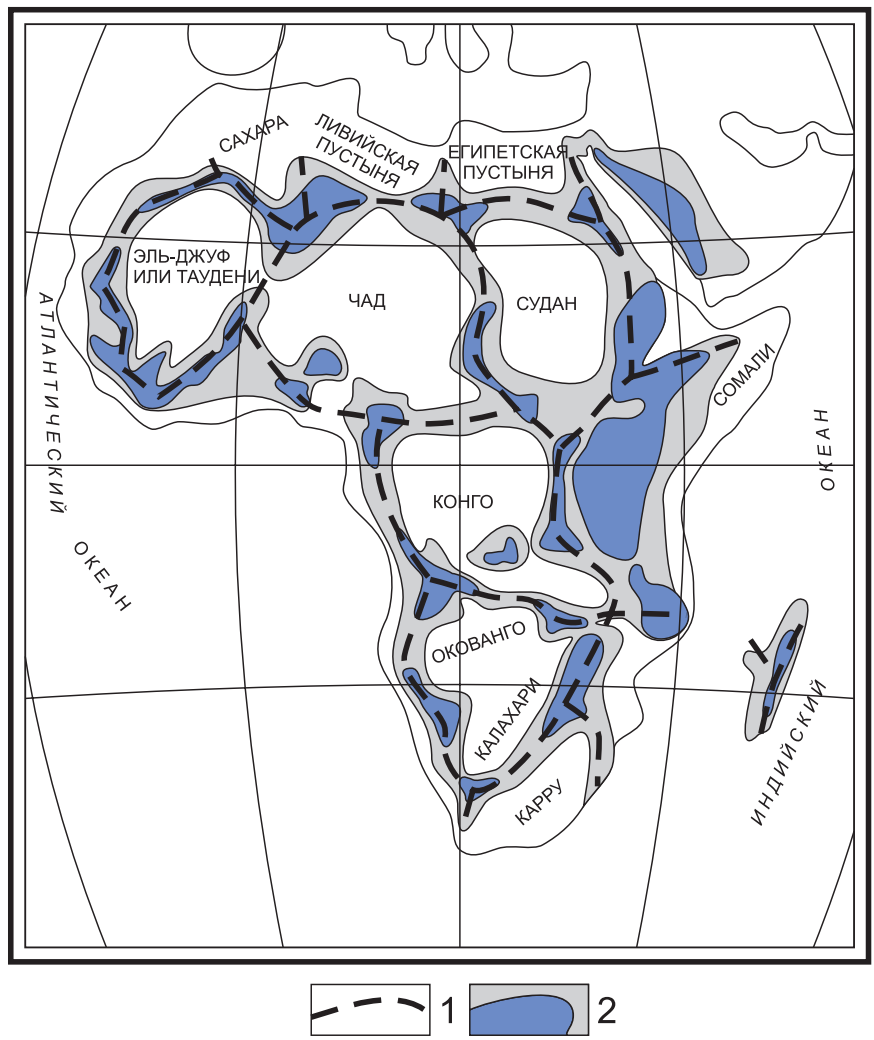

Рис. 4б. Новейшие надрегиональные структуры гравитационной неустойчивости Земли шестого порядка Африканского континента [Реtrov, 2007]. 1 - границы структур гравитационной неустойчивости с всплыванием в центре и погружением в краевых частях; 2 - погружающиеся (белое) и всплывающие (синее) участки структур гравитационной неустойчивости.

Fig. 4b. The recent supra-regional structures (of the sixth order) of gravitational instability of the Earth in Africa [Petrov, 2007]. 1 - boundaries of structures of gravitational instability with emerging centres and sinking marginal areas; 2 - sinking (white) and emerging (blue) parts of structures of gravitational instability. 


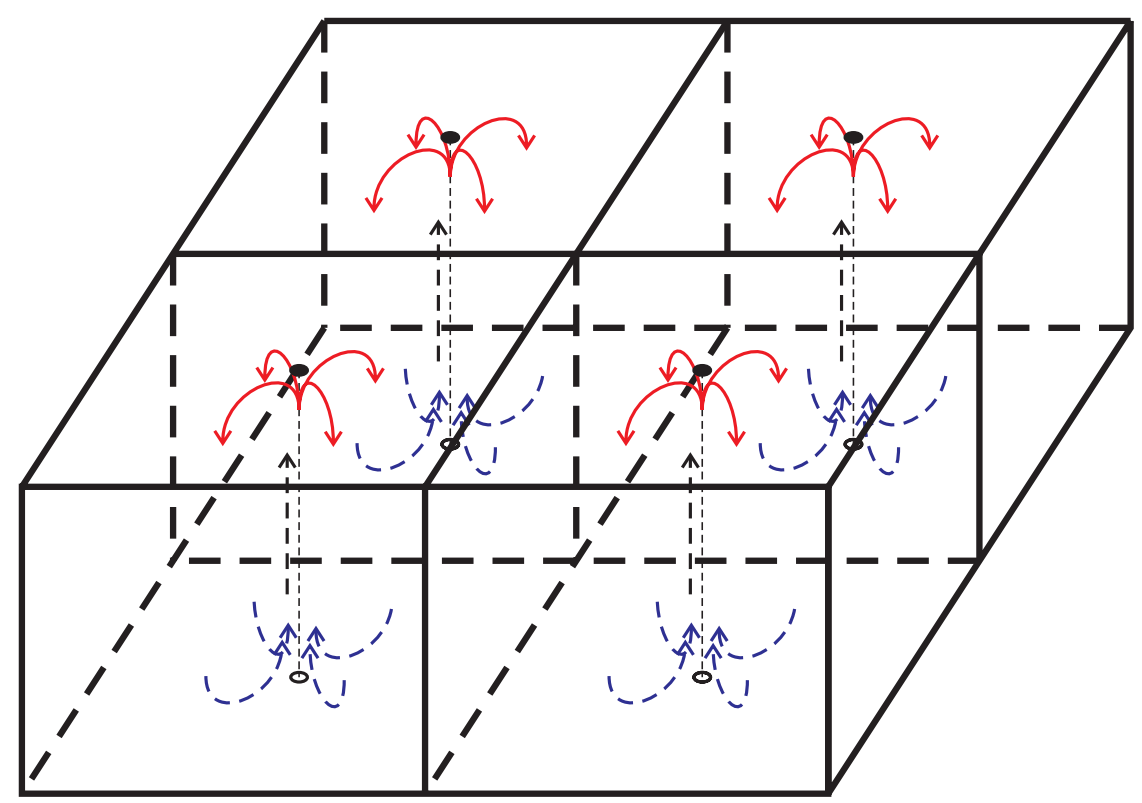

Рис. 5. Схема формирования ячей Бенара и заложение крупнейших разломов и блоковых структур литосферы на межъячеистых границах в остывающей литосфере Земли. Цветом выделены направления конвекционных течений горячих (красное) и охлажденных (черное) масс в конвекционной ячее.

Fig. 5. The scheme of formation of Benard cells and origination of major faults and block structures of the lithosphere at boundaries between the cells in the cooling lithosphere of the Earth. In convention cells, convection flows of hot masses are shown in red, and convection flows of cooling masses are shown in black.

нента [Petrov, 2007]. В цитируемой работе формирующимся на ранней стадии развития региональным структурам, в последующем отражающимся в новейших надрегиональных структурах, придается большое организующее начало.

Ячеи Бенара не впервые используются в геологии. Первоначально на них ссылались для объяснения формирования первичных континентальных ядер. Обращение П.В. Макарова и коллег к ячеям Бенара для заложения первичной наиболее редкой системы разломов и крупных блоков способствует пониманию происхождения самых крупных блоков литосферы. Именно консервирующиеся в литосфере ячеи Бенара, нижняя граница которых корреспондировала с одной из главных границ ее горизонтальной расслоенности, предопределила первоначальную масштабно-временную разломно-блоковую структуру литосферы (рис. 5). Ее дальнейшая эволюция представляется нам в свете уже известных закономерностей дробления твердых тел.

Сформировавшаяся к концу протерозоя разломноблоковая структура литосферы благоприятствовала, с одной стороны, дальнейшему раздвижению блоков, «расплыванию» в соответствии с мантийными конвекционными потоками, а с другой - их скучиванию, сдавливанию и сдвиганию. При таких изменениях в напряженном состоянии блоки приобретали различную степень векторной подвижности - от дополнительного раздвижения и относительно стесненного сдвигания до надвигания и полной неподвижности, «запирания». В зависимости от формы блоков и их относительной подвижности при вариациях постоянно возобновляемых региональных напряжений изменяются способы их разрядки. Подвижные межблоковые контакты способствуют непосредственной реализации напряжений. При очень жестких межблоковых «контактах» разрядка напряжений происходит внутри блока, формируя разломно-блоковую структуру очередного масштабного и временного уровня (рис. 6). Аналогичные ситуации могут возникать и при втором, и при последующих масштабно-временных уровнях делимости литосферных блоков. В итоге в литосфере не только формируется разноранговая разломно-блоковая делимость, но и ее разная интенсивность и «кусковатость» в зависимости от количества вариаций напряжений и ситуаций ограниченности, вплоть до «запертости», «блокированности» конкретных блоков при очередных тектонических активизациях. Наиболее наглядными примерами могут явиться карты разломноблоковых структур платформенных и горно-складчатых, активных, рифтовых или коллизионных систем Земли. Несколько из перечисленных на разных масштабных уровнях приводятся на рис. 7, 8, 9. В приведенных примерах - почти полное сочетание блоков различных рангов. Отсутствуют мелкие блоки в зонах деструкции и наблюдаемая в обнажениях раздробленность. Сложность заключается в заложении первичных блоковых структур литосферы. 


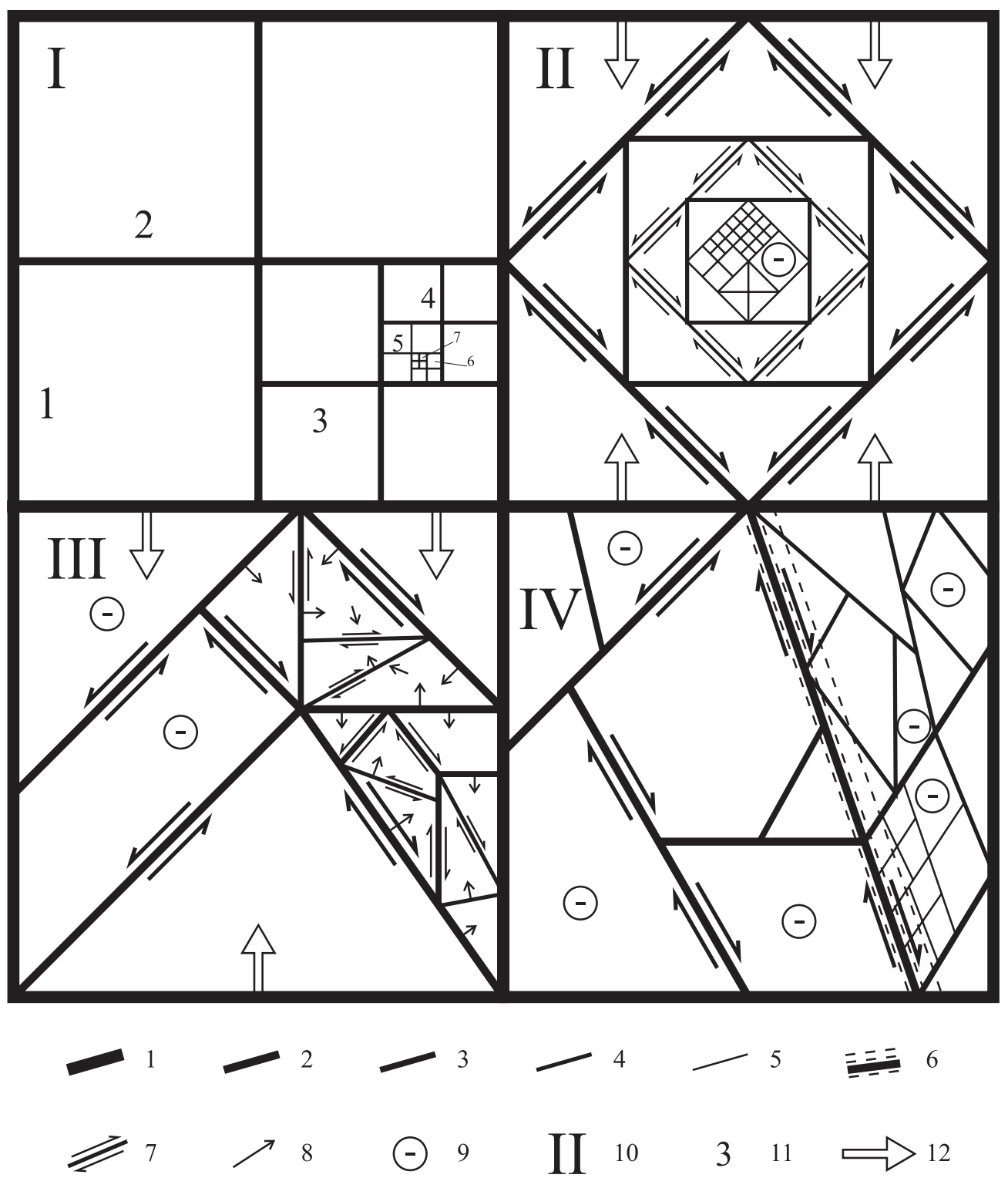

Рис. 6. Различные условия образования и формы разломно-блоковых структур в верхней хрупкой части литосферы. 1-5 - границы блоков первого, второго, третьего, четвертого и пятого рангов соответственно; 6 - зона современной деструкции литосферы на границе блоков; 7 - сдвиговые смещения на межблоковых границах; 8 - вектор локальных сил; 9 - стабильные блоки; 10 - варианты развития разломно-блоковых структур в литосфере; 11 - ранги блоков; 12 - вектор внешних тектонических сил.

Fig. 6. Various conditions for formation and shapes of fault-block structures in the upper brittle part of the lithosphere. 1-5 - boundaries of blocks of the first, second, third, fourth and fifth ranks, respectively; 6 - the zone of recent fracturing of the lithosphere at the borders of the blocks; 7 shear displacement at boundaries between the blocks; 8 - vector of local forces; 9 - stable blocks; 10 - variants of development of fault-block structures in the lithosphere; 11 - ranks of blocks; 12 - vector of external tectonic forces.

Существующими методами исследований установить возраст заложения первичных разломов Земли практически невозможно. Имеется в виду разграничение между архейским и протерозойским периодами формирования литосферы. Опираясь на установленные закономерности ранних этапов развития Земли и становления ее верхней оболочки - литосферы, можно утверждать, что при ее остывании в вязкой среде формировались конвекционные ячеи, наиболее «холодные» границы между которыми явились концентраторами напряжений, способствующих заложению дисло- каций. Об этом уже упоминалось выше. Разрывы такого типа первичного заложения весьма трудно диагностировать среди других крупных разломов литосферы. Косвенное доказательство наличия в ансамбле крупных межблоковых разрывов различных по своей геологической значимости разновидностей можно найти в работах известного специалиста по блоковой тектонике литосферы Ю.Г. Гатинского и коллег [Gatinsky et al., 2008, 2011a, 2011b; Gatinsky, Rundquist, 2009]. В частности, в коллективной статье Ю.Г. Гатинского и др. [Gatinsky et al., 2011b] приведена карта межблоко- 


\section{КАРТА ДЕСТРУКТИВНЫХ ЗОН ЦЕНТРАЛЬНОЙ АЗИИ}

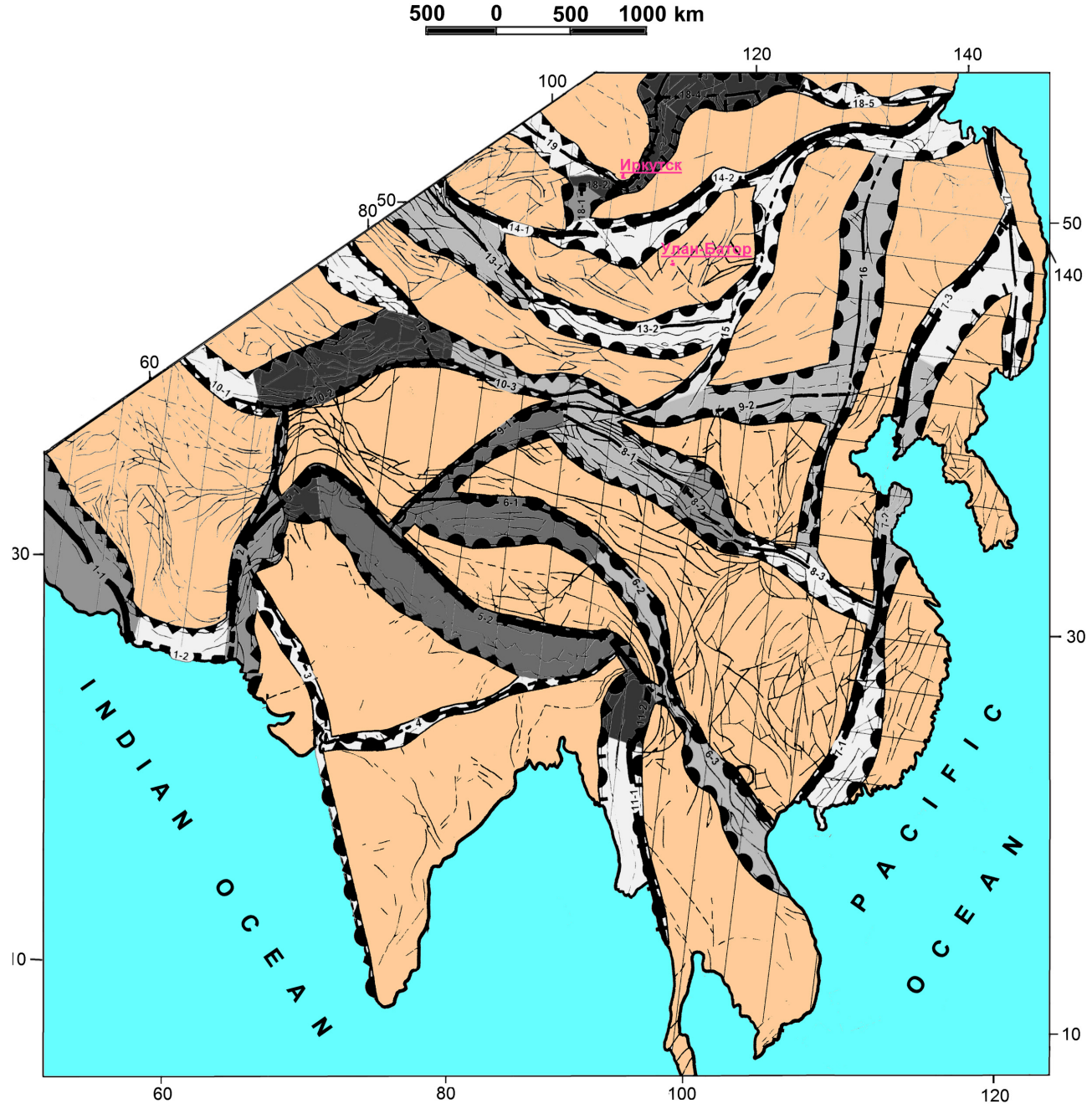

УСЛОВНЫЕ ОБОЗНАЧЕНИЯ

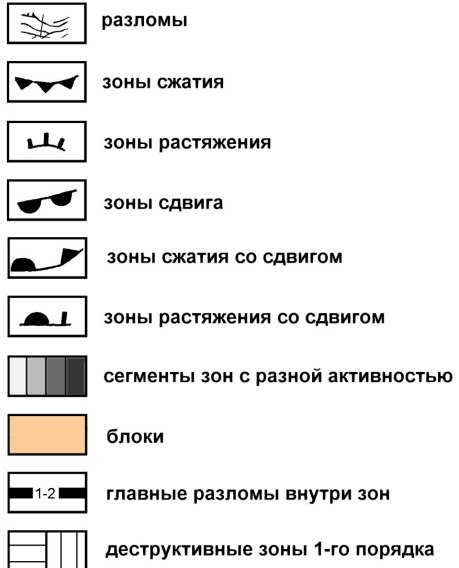

Рис. 7. Разломно-блоковая тектоника Азии [Sherman et al., 2005c].

Fig. 7. Fault-block tectonics of Asia [Sherman et al., 2005c].

вых зон (которыми являются крупные разломы литосферы) и локализации катастрофических землетрясений Центральной Азии. Отчетливо видно, что эпицентры катастрофических землетрясений приурочены к «избранным» межблоковым разломам. И только в пределах некоторых из этих зон высвобождается значительное количество сейсмической энергии. Проведенные авторами подсчеты сейсмической энергии показали, что на рассматриваемой ими значительной территории Азии наиболее активными и, соответственно, наиболее сейсмоопасными являются межблоковые зоны, ограничивающие блоки Памир, Тянь-Шань, Гималаи и Баян-Хар, и некоторые другие, ограничивающие Центрально-Азиатскую и Восточно-Азиатскую транзитные зоны (рис. 9). Эти блоки обладают мощными литосферными корнями до глубин, превышающих 200 км, характеризуются повышенной жесткостью и наиболее слабой деформированностью во внутренних частях. Вместе с тем можно думать, что вещество ли- тосферы под рядом блоков находится на разных глубинах в квазипластичном состоянии [Gatinsky et al., $2011 b]$. Изложенные факты позволяют говорить о том, что характеризуемые межблоковые крупные разломы территории Азии могут отличаться друг от друга и глубинностью, и интенсивностью современной активизации, и другими признаками, достаточно подробно описанными в цитируемой статье. Для обсуждаемого нами вопроса важен факт установления различных характеристик для широкого класса крупных сейсмоактивных разломов Азии, фиксируемый одним из авторитетных исследователей блоковых структур ее литосферы. Более того, в ранней публикации [Gatinsky et al., 2008, p. 40] отмечено, что в Центральной Азии наиболее активными наряду с границами плит являются межблоковые зоны, ограничивающие Памир, Тянь-Шань и другие горные системы. По энергетическому потенциалу эти зоны характеризуются максимальным выделением сейсмической энергии, которое 


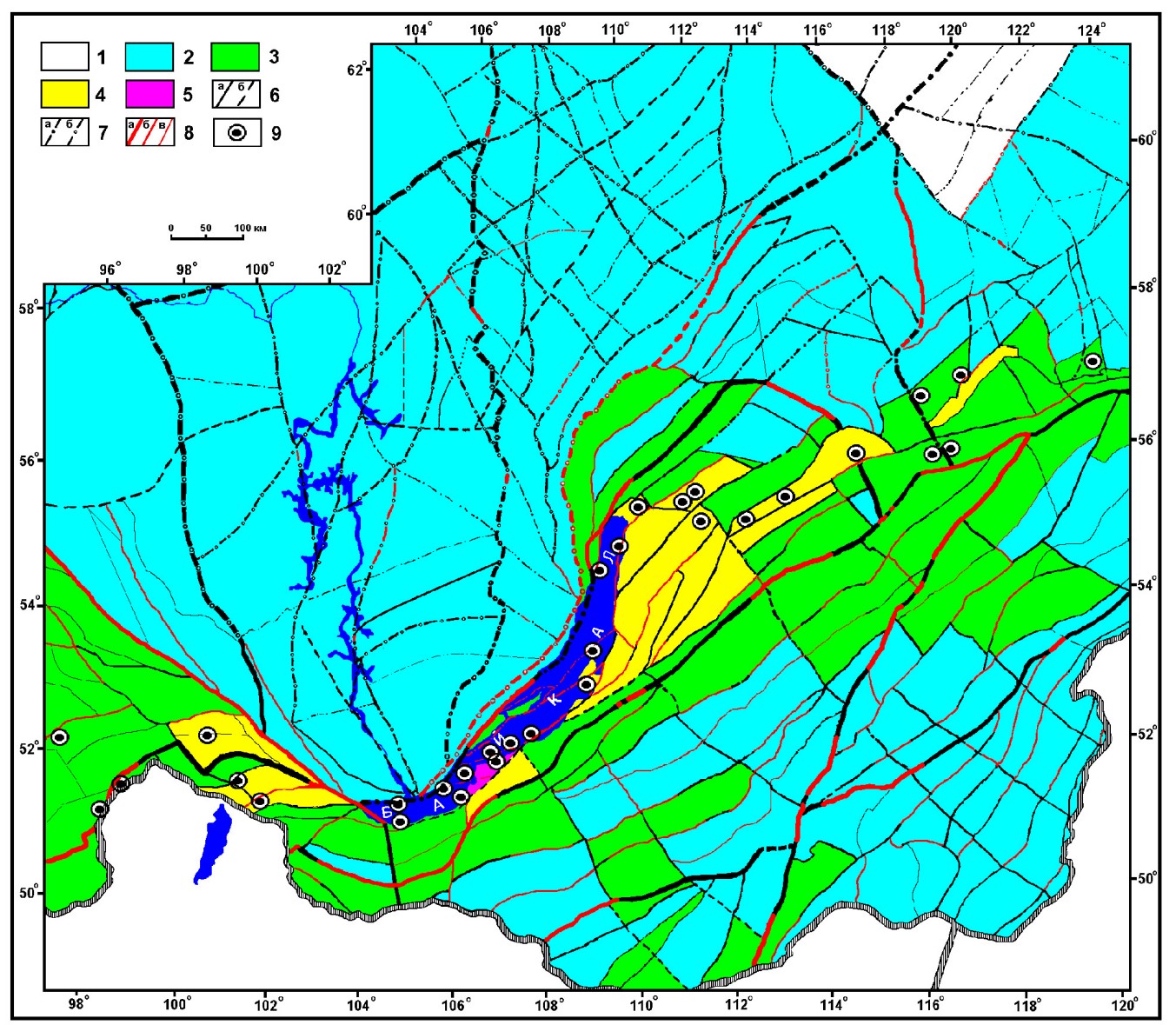

Рис. 8. Схема разломно-блоковых структур юга Восточной Сибири и их относительной стабильности [Sherman et al., 1996]. 1-5 - степень стабильности разломно-блоковых структур: 1 - стабильные, 2 - относительно стабильные, 3 - относительно нестабильные, 4 - нестабильные, 5 - весьма нестабильные; 6 - разломы: а - установленные, б - предполагаемые; 7 - разломы под осадочным чехлом платформы: а - установленные, б - предполагаемые; 8 - активизированные участки разломов: а - трансрегиональных, б -- региональных, в - локальных; 9 - эпицентры зафиксированных сильных землетрясений $(K>13)$.

Fig. 8. The scheme of fault-block structures of the Southern East Siberia, and their relative stability [Sherman et al., 1996]. 1-5 - degrees of stability of fault-block structures: 1 - stable, 2 - relatively stable, 3 - relatively unstable, 4 - unstable, 5 - very unstable; 6 - faults: a - established, $\sigma$ - estimated; 7 - faults under the sedimentary cover of the platform: a - established, $\sigma$ - estimated; 8 - activated segments of faults: a - transregional, 6 - regional, в - local; 9 - epicenters of recorded strong earthquakes $(K>13)$.

сопоставимо с сейсмической энергией, выделяемой в зонах субдукции, но внутриконтинентальные зоны уступают субдукционным по глубине своего проникновения в литосферу. Основные выводы по интересующему нас вопросу о межблоковых границах с разными характеристиками (с разной природой происхождения по С.И. Шерману в настоящей статье) с годами у Ю.Г. Гатинского и коллег не изменились, что закрепляет наши представления о разной природе зарождения межблоковых разломов в континентальной литосфере. Можно заключить, что блоковая делимость литосферы происходит на двух масштабно-временных уровнях. Первоначально в литосфере формируются крупные блоки первого и, возможно, второго рангов, определяющие первый масштабно-временной уровень крупных блоковых структур литосферы (см. рис. 6 ). В границах блоков первого масштабно-временного уровня в процессе геодинамического развития и реализа- ции тектонических напряжений селективно образуются более мелкие блоки других рангов, формирующие второй масштабно-временной уровень деструкции литосферы. Интенсивность развития блоков на втором уровне зависит от локальной ориентации их ограничений по отношению к ориентировке напряжений и формам их реализаций. Общее количество рангов блоковых структур определяется типом геодинамических режимов континентальных территорий и вызванных ими активизаций.

Таким образом, литосфера, как структура мегамасштабная, не может сводиться к свойствам геоматериала аналогичной структуры в более крупных масштабах, т.е. в масштабах, в которых проявляются свойства локальных структур. Разломно-блоковая структура литосферы представляет собой мультисложную во времени и пространстве двухуровневую масштабно-временную дискретную структуру, эволюционная де- 


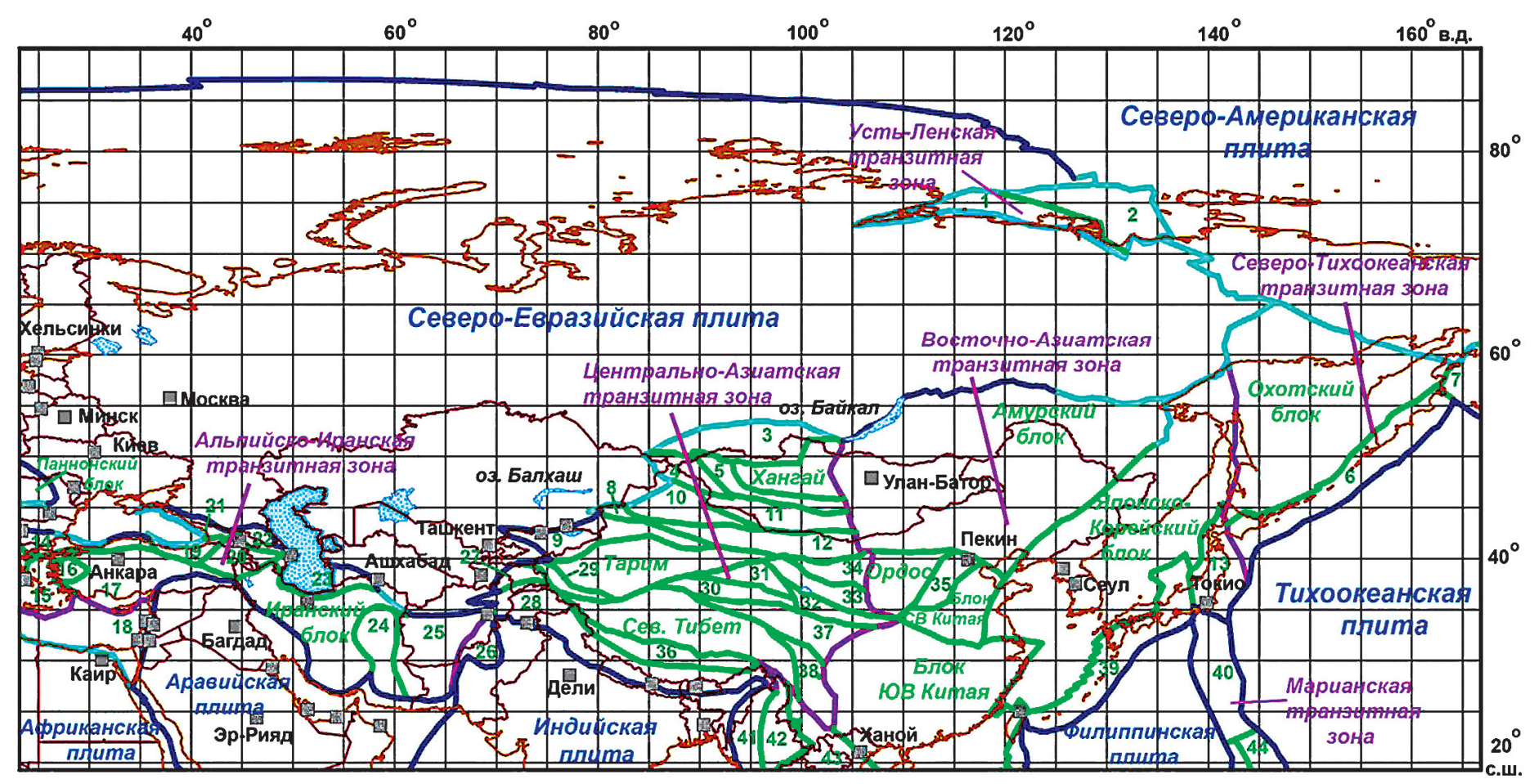

Рис. 9. Схема плитно-блокового строения Северной и Центральной Евразии [Gatinsky et al., 2011b]. Границы: синие - главных литосферных плит, фиолетовые - транзитных зон, зеленые - блоков, голубые - предполагаемые границы структур, коричневые - границы стран и береговая линия. Цифрами обозначены блоки: 1 - Усть-Ленский, 2 - Центрально-Лаптевский, 3 - Саянский, 4 - Алтайский, 5 Западно-Монгольский, 6 - Курило-Камчатский, 7 - Берингия, 8 - Эби-Нур, 9 - Тянь-Шань, 10 - Джунгария, 11 - Южная Гоби, 12 - БейШань, 13 - Северо-Японский, 14 - Родопо-Синопский, 15 - Эгейский, 16 - Мендерес, 17 - Анатолийский, 18 - Восточно-Средиземноморский, 19 - Восточный Понт, 20 - Малый Кавказ, 21 - Западный Кавказ, 22 - Восточный Кавказ, 23 - Южно-Каспийский, 24 - Лут, 25 - Афганский, 26 - Пенджаб, 27 - Памир, 28 - Гималаи, 29 - Западный Тарим, 30 - Восточный Кунлунь, 31 - Цайдам, 32 - Западный Цинлинь, 33 - Цилянь, 34 - Джартай, 35 - Тайханг-Шань, 36 - Южный Тибет, 37 - Баян-Хар, 38 - Кам-Диан, 39 - Рюкю - Центральный Хонсю, 40 - Идзу-Бонинский, 41 - Андаманы - Западная Мьянма, 42 - Шан, 43 - Индокитайско-Зондский, 44 - Восточно-Марианский.

Fig. 9. The scheme of the plate-block structure of Northern and Central Eurasia [Gatinsky et al., 2011b]. Colours of boundaries: blue - main tectonic plates, purple - transit zones, green - blocks, blue - assumed boundaries of structures, brown - borders of countries and coastlines. Blocks are numbered: 1 - Ust-Lensky, 2 - Central Laptev, 3 - Sayan, 4 - Altai, 5 - Western Mongolian, 6 - Kuril-Kamchatka, 7 - Beringia, 8 - EbiNoor, 9 - Tien Shan, 10 - Dzungaria, 11 - South Gobi, 12 - Bei-Shan, 13 - North Japan, 14 - Rodopi-Sinop, 15 - Aegean, 16 - Menderes, 17 Anatolian, 18 - East Mediterranean, 19 - East Pont, 20 - Lesser Caucasus, 21 - Western Caucasus, 22 - Eastern Caucasus, 23 - Southern Caspian, 24 - Lute, 25 - Afghan, 26 - Punjab, 27 - Pamir, 28 - Himalaya, 29 - Western Tarim, 30 - Eastern Kunlun, 31 - Tsaidam, 32 - Western Qinglin, 33 - Tsilyan, 34 - Dzhartay, 35 - Tayhang Shan, 36 - Southern Tibet, 37 - Bayan Har, 38 - Kam-Dian, 39 - Ryukyu-Central Honshu, 40 - Idzu-Bonin, 41 - Andaman-Western Myanmar, 42 - Shan, 43 - Indochina-Sunda, 44 - Eastern Marianas.

струкция которой на современном этапе развития охватывает преимущественно второй уровень - разломы и блоки трансрегионального, регионального и более детальных масштабов. Именно для них характерна закономерная деструкция, описываемая аналитическими уравнениями.

\section{4. МЕЖБЛОКОВЫЕ ГРАНИЦЫ И ЛОКАЛЬНЫЕ РАЗЛОМЫ КАК ГЛАВНЫЕ КОМПОНЕНТЫ ДЕСТРУКЦИИ И САМОСТОЯТЕЛЬНЫЕ ГЕОЛОГИЧЕСКИЕ ТЕЛА}

В зависимости от постановки задачи структура литосферы принимается как континуумная или дискретная. В дальнейшем изложении в допустимых пределах будем рассматривать литосферу как твердое тело, а разрывы - как результат нагружения и первоначальной концентрации напряжений на локальных местах, где на микроскопических уровнях зарождаются нарушения, дальнейшая эволюция которых приводит к формированию трещин, разломов различных рангов и их систем.

K настоящему времени накоплен значительный объем экспериментальных данных и наблюдений на геологических объектах, позволяющих сделать заключение о том, что процесс разрушения хрупких тел обладает свойствами иерархического самоподобия мультискейлинга, причем принцип универсальной делимости может быть распространен на микро- и мезоуровни [Kocharyan, Spivak, 2003; Makarov, 2004; Makarov et al., 2007; Sherman et al., 1999; Sherman, Gladkov, 1999]. Это главнейшее общее свойство деструкции литосферы. Естественно, оно корреспондирует с тем же свойством ранговой разломно-блоковой дели- 
мости литосферы начиная с ее второго или третьего масштабно-временного уровня.

Одновременно межблоковые границы (зоны разломов) и отдельные разломы внутри блоков представляют собой большую самостоятельную область исследований. К настоящему времени четко сформировалось представление о разломах как объемных телах, характеризующихся определенной внутренней структурой, параметрами и кинематикой движений крыльев. Последнее свойство - нестабильность граничных сочленений, вариации геофизических полей и постоянное эволюционное развитие (даже при сохранении неизменными внешних региональных напряжений) - наиболее ярко отличает разломы от других геологических тел. Остановимся на существенно важных индивидуальных свойствах разломов, определяющих их и как составной компонент деструкции, и в то же время как самостоятельные геологические тела.

\section{5. ОБЛАСТИ ДИНАМИЧЕСКОГО ВЛИЯНИЯ РАЗЛОМОВ И ИХ МОДЕЛИ}

В зависимости от целей и детализации исследований разломы можно последовательно представлять как двух- и трехмерные тела в пространстве, которые, в свою очередь, из-за нестабильности развития и большинства случаев неоднократных активизаций необходимо рассматривать в координатах времени. Было введено понятие «область динамического влияния разломов», которое обозначает часть окружающего разлом во всех трех измерениях пространства, на котором проявляются остаточные, необратимые (пластические или разрывные) и обратимые во времени (упругие, а также геофизические поля и др.) следы деформаций и возмущений, вызванные формированием разлома и подвижками по нему [Sherman et al., 1983]. Понятие «область динамического влияния» к настоящему времени широко используется в публикациях при анализе разломов как структур, контролирующих локализацию кратко- и долговременных геологических явлений. Ширина области динамического влияния разломов определяется рядом параметров, но главным образом толщиной слоя, вовлеченного в деформирование, и длиной разрывов. При детальном картировании по латерали область динамического влияния подразделяется на зоны. От центральной осевой линии разлома, как правило, симметрично по обе ее стороны последовательно выделяются зоны: 1 - интенсивного деформирования и дробления пород, 2 - повышенной трещиноватости, вызванной движениями по сместителю, и 3 - незначительных вариаций напряженного состояния, величины модификации которого не находят отражения в вещественном и структурном преобразовании вещества в околоразломном пространстве [Sherman, 2004]. По вертикали - третье измерение разломатела - отражается изменение реологических свойств среды, что позволяет выделить пять зон: 1 и 2 - хрупкого и квазихрупкого разрушения, 3, 4 и 5 - квазипластического, пластического и вязкого течения, что соответствует принципиальной схеме распределения напряжений по С.И. Шерману [Sherman, 1997, 2004] (рис. 10, $a, 6,11)$. Границы между зонами неотчетливые с постепенными переходами от одной к другой. Глубины границ зависят от геодинамических режимов, типов напряженного состояния литосферы и генетически связанных с ними морфологогенетических разновидностей разломов. Латеральная зональность строения разломов с вариациями интенсивности зон дробления по комплексу экспериментальных и геологических данных изучена С. Шольцем (рис. 10, б) [Scholz, 2002]. Такое зональное строение крупных разломов литосферы приемлемо объясняет проявление в границах областей их динамического влияния ряда геологогеофизических процессов и структур. Они формируются при развитии разлома, консервативны в пространстве и времени и в совокупности могут рассматриваться как стационарная модель разлома (рис. 11, a).

Новая модель зональной структуры разломов недавно предложена А.А. Спиваком и В.М. Цветковым [Spivak, Tsvetkov, 2009; Spivak, 2011]. Разлом рассматривается как геологическое тело, представленное горной породой с разной степенью дробления в зависимости от расстояния до его середины. Модель описывает зависимость ширины зоны разлома от величины дифференциальной подвижки берегов в результате сдвига. Основным механизмом увеличения ширины зоны разлома является дальнейшее дробление пород, заполняющих зону. Зональную структуру разлома образуют три зоны: срединная А, в которой фиксируется предельная степень дробления; примыкающая к ней с двух сторон зона В, представленная горными породами со средним размером отдельностей; и внешняя периферийная зона С, расположенная на контакте с относительно не нарушенными горными породами. Положение внешних границ зоны С определяет общую ширину зоны разлома. Предложено уравнение, нелинейно связывающее ширину разлома с амплитудой сдвига его берегов. Как видим, модель несколько упрощает представления С. Шольца [Scholz, 2002] и С.И. Шермана [Sherman, 2004].

Дальнейшие разработки и уточнения понятия «область динамического влияния разломов» привели к введению понятия «сейсмогенная ширина разломной зоны» [Kocharyan et al., 2010, 2011] - области, в которой сосредоточена основная часть землетрясений, приуроченных к рассматриваемой структурной единице. Явно выделяющаяся линейная область наибольшей концентрации очагов событий совпадает с местоположением магистральной линии разлома - его оси. Принимая за сейсмогенную ширину разломной зоны средний размер области, в которой расположены гипоцентры 75 \% событий, и обобщая эти данные, авторы предложили соотношение, связывающее сейсмоген- 

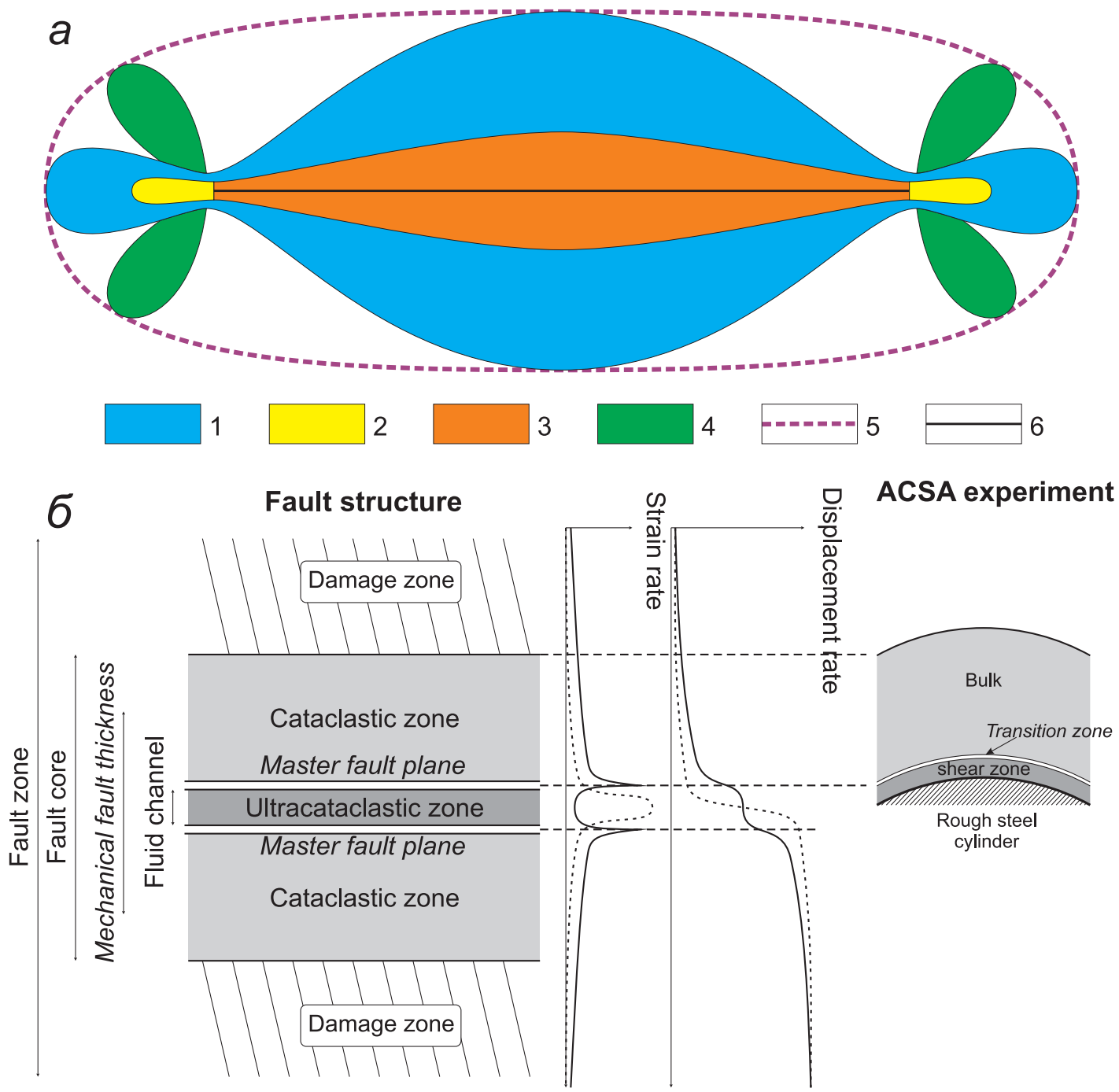

Рис. 10. Латеральная зональность строения разломов. $a$ - принципиальная модель распределения напряжений вокруг трещины ([Gzovsky, 1975], с добавлениями автора). 1 - область повышения напряжений; 2 - область интенсивного повышения напряжений; 3 - область снижения напряжений; 4 - область слабого снижения напряжений; 5 - граница области динамического влияния разлома; 6 - осевая линия разлома. б - распределение типов тектонитов и скоростей деформаций по поперечному сечению зоны разлома [Scholz, 2002].

Fig. 10. Lateral zonation of the fault structure. $a$ - the basic model of distribution of stresses around the fracture ([Gzovsky, 1975], with the author's additions). 1 - area of higher stress values; 2 - area of intensive increase of stresses; 3 - area of reduced stresses; 4 - area of minor reduction of stresses; 5 - boundary of the area of dynamic influence of the fault; 6 - axial line of the fault. $\sigma$ - distribution of types of tectonites and strain rates in the cross-section of the fault zone [Scholz, 2002].

ную ширину разломной зоны с ее длиной.

Детальные исследования межблоковых зон [Kocharyan, Spivak, 2003] позволили определить вариации их деформационных характеристик в широком диапазоне размеров. Установлено, что величина нормальной жесткости межблоковой границы нелинейно снижается по мере увеличения ее длины. Это означает, что протяженные разломы оказываются относительно более чувствительными к вариациям напряженного состояния по сравнению с рядом расположенными более короткими разрывами. Ослабление «чувствительности» может относиться и к протяженным разрывам, с эшелонированной, сегментированной внутренней структурой [Kocharyan et al., 2010]. Предложено урав- нение, связывающее жесткость межблоковой разломной зоны с ее длиной (рис. 12):

$$
k=837 L^{-0.41}
$$

где $k$ - жесткость, МПа/м, $L$ - длина разлома, км, что неплохо совпадает со связью ширины разломной зоны с длиной разлома по данным этих же авторов:

$$
w=0.85 L^{0.42},
$$

где $w$ - ширина разломной зоны, км.

Последнее уравнение несколько уточняет общие данные о ширине разломных зон, приведенные в ра- 


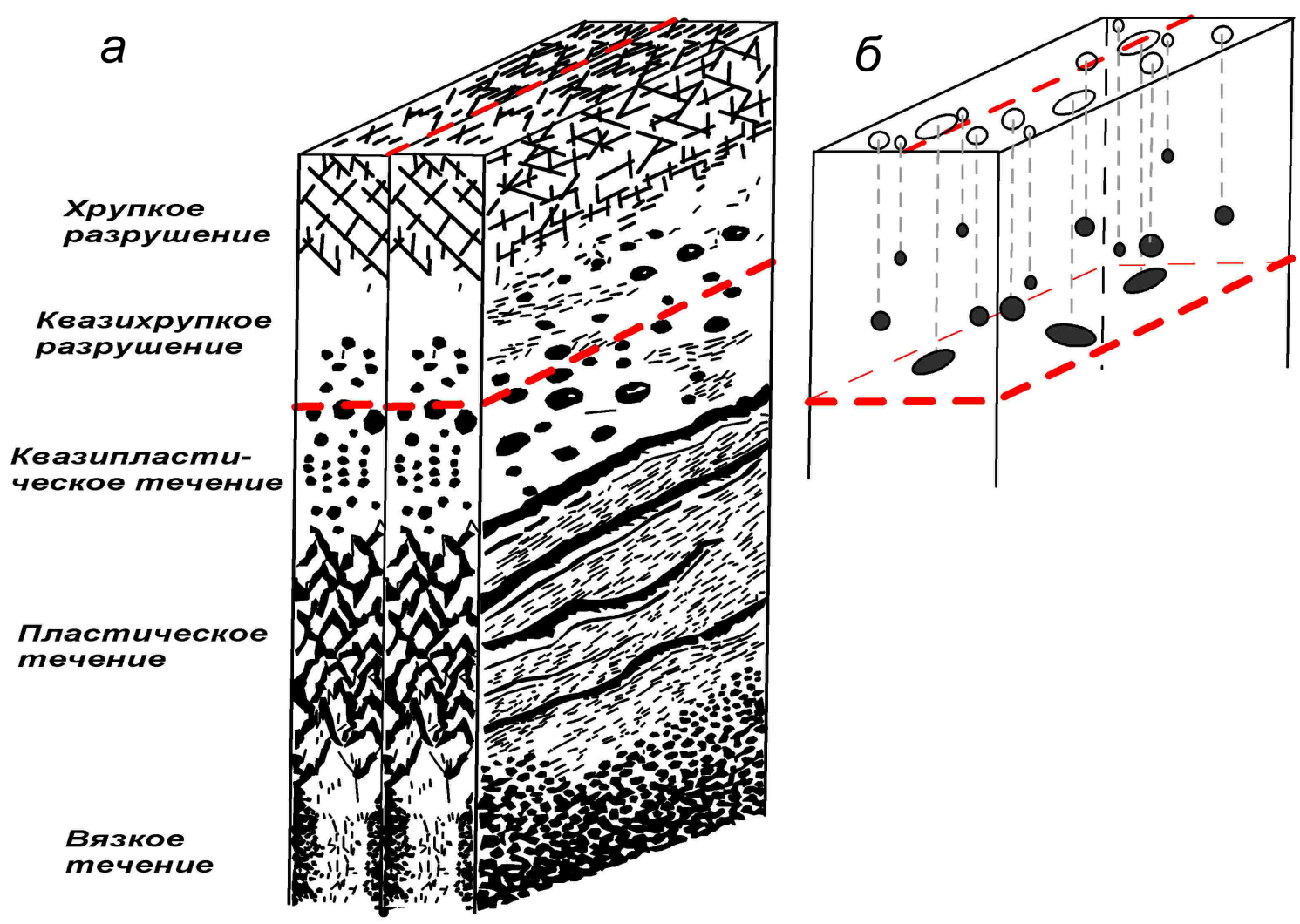

Рис. 11. Стационарная (a) и нестационарная (б) модели разломов. На стационарной модели отражен вертикальный реологический разрез литосферы, на котором глубины горизонтальных границ между формами локальных структурных формирований изменяются в зависимости от типа напряженного состояния литосферы. На нестационарной, изменяющейся во времени модели разломов показаны очаги землетрясений, разновременно зарождающиеся в различных местах по сечению и простиранию разрыва, отражающие временные вариации различных физических полей околоразломной сред.

Fig. 11. Stationary (a) and non-stationary (б) fault models. The stationary model shows the vertical rheological profile of the lithosphere, where horizontal boundaries between structural units are located at various depths depending on types of the state of stresses of the lithosphere. The nonstationary, time-varying fault model shows earthquake foci that originate at different times in different locations across the section and along the strike of the fault; they reflect temporal variations of different physical fields of the near-fault medium.

боте [Sherman et al., 1991], и справедливо относит их только к сейсмогенной ширине разломных зон [Коcharyan et al., 2010]. Заметим, что в преобладающем большинстве случаев плотность очагов в сейсмической зоне в целом неравномерная, со временем накапливаются данные и, возможно, становится более равномерной плотность очагов.

Снижение прочностных свойств среды при постоянном региональном напряжении приводит к увеличению скорости деформации. В сейсмически активных регионах отмеченный в работах Г.Г. Кочаряна и коллег эффект снижения прочности разломных зон в зависимости от их длины может пояснить и относительно более высокую интенсивность сейсмических событий в областях динамического влияния наиболее протяженных разломов, в том числе в связи с их повышенной «чувствительностью» к короткопериодной активизации, генерируемой деформационными волнами [Sherman, 2009a].

Понижение прочностных свойств внутриразломной среды отражается на рекуррентном времени последо- вательностей повторных землетрясений в зависимости от сейсмического момента. Используя опубликованные материалы по повторным землетрясениям Калифорнии, Японии, Тайваня, а также Прибайкалья, Г.Г. Кочарян [Kocharyan, 2010] показал зависимость рекурентного времени $\tau$ (годы) от сейсмического момента $M_{0}$ :

$$
\tau \sim M_{0}^{0.17},
$$

где $M_{0}=S \cdot \Delta L$, при $S$ - площадь разрыва, $\Delta L$ - амплитуда смещения.

Приведенные новые, а также другие известные факты показывают, что стационарная модель разломов не объясняет дискретности вариаций геологических формирований (для «геологического» масштаба времени), сейсмических и других современных событий (для реального времени) в локальных местах большого объема области динамического влияния разломов. Детализация стационарной модели достигается путем ее «совмещения» с нестационарной, в базу которой положен 


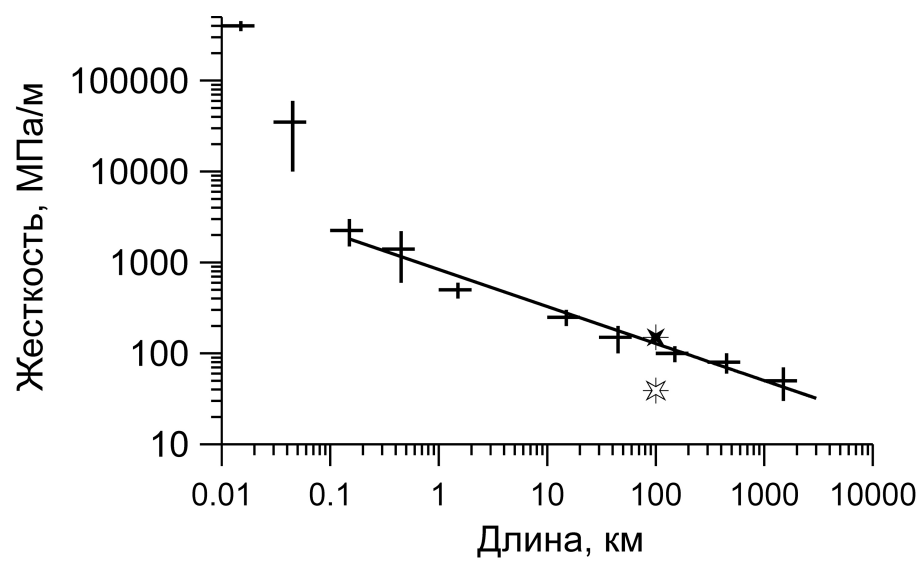

Рис. 12. Зависимость нормальной жесткости межблоковых промежутков от линейного масштаба [Kocharyan et al., 2010].

Fig. 12. The dependence of the normal rigidity of inter-block intervals from the linear scale [Kocharyan et al., 2010].

фактор времени. Именно это обстоятельство еще раз подтверждает необходимость введения понятия «нестационарная модель разломов», вариации различных свойств разломов в областях их динамического влияния и времени [Sherman, 2004]. Временная, нестационарная, модель разломов (см. рис. 11, б) призвана обосновать критерии, определяющие их вариации во времени и пространстве, в том числе контролирующие функции. Временные изменения проницаемости (магматизма, флюидопроницаемости и т.п.), сейсмичности или, другими словами, нарушения стабильности в областях динамического влияния разломов особенно важны в границах реального для социума времени текущего столетнего периода и его последних десятилетий. Нарушения стабильности, постоянства в свойствах и кинематике разломов, в какой бы форме они ни проявлялись, отражают их активизацию. Анализ периодичности активизаций разломов в короткие временные интервалы дает возможность прогнозировать «приразломные» события, особенно сейсмичность [Sherman, 2009a]. Введение понятия «нестационарная модель разломов», отражающего вариации их геофизических, в том числе волновых, полей и кинематических характеристик в короткопериодные интервалы времени, дает основания рассматривать разломы как сложные геологические тела в пространственно-временном измерении [Sherman, 2004, 2005; Sherman, Savitsky, 2006; Sherman, Gorbunova, 2008; Sherman et al., 2012].

Таким образом, комплексная тектонофизическая модель крупного разлома литосферы, как четырехмерного геологического тела в пространстве и времени, объединяющая стационарную и нестационарную составляющие, открывает новые возможности для рассмотрения параметров разломов в широком диапазоне их количественных внутренних взаимосвязей, а также во взаимоотношениях с синхронно протекающими процессами. Показательным примером являются разработки Г.Г. Кочаряна [Kocharyan, 2010], рассматривающего разломную зону как нелинейную механическую систему. Отсюда следует, что отклик разломной зоны на некоторые внешние воздействия может быть не пропорционален энергии источника воздействия. Это обстоятельство позволяет подвергнуть анализу постоянно возникающие в литосфере Земли волновые процессы с невысоким энергетическим потенциалом в качестве вероятного триггерного механизма короткопериодной активизации разломов.

\section{6. КОРОТКОПЕРИОДНАЯ АКТИВИЗАЦИЯ РАЗЛОМОВ И РАЗЛОМНО-БЛОКОВЫХ СТРУКТУР В РЕАЛЬНОМ ВРЕМЕНИ}

Активизация разломов и разломно-блоковых структур литосферы - серьезный и важный тектонический процесс. С ним в геотектонике связываются многие практически значимые явления - от формирования принципиально новых структур до проявления новых процессов и концентрации полезных минеральных ассоциаций. Понятие «активизация» широко и неоднозначно используется в разломной тектонике. Некоторые разночтения в применении этого термина у разных авторов определяются теми признаками активных разломов, которые берутся за основу понятия. Возникает вопрос возраста и активизации глубинных разломов, что, как писал А.В. Пейве [Peive, 1990], - не простая проблема. Несмотря на отдельные разногласия, многие исследователи вкладывают в понятие активизации разломов представление об изменении режима их развития. Оно ведет к эволюционному формированию конкретных разрывных структур, часть из которых унаследует только пространственное положение, другая приобретает новые векторы смещений и генетическое содержание. Тектоническая активизация как процесс существенно влияет на густоту сетки разломов, стимулируя избирательное разрастание разрывов в длину и слияние коллинеарно расположенных мелких трещин и коротких разрывов в единый магистральный разрыв.

Уточнение временного интервала в объеме понятия «активизация разломов» весьма важно на современном этапе развития тектонофизики. В понимании автора активными следует считать разрывы, геолого-геофизические процессы в областях динамического влияния которых происходят в настоящее реальное время (месяцы, годы, первые десятилетия) или происходили не более чем в предшествовавший столетний период. Для столь детальной временной оценки вариаций активности разломов методов не много. Только три группы методов могут помочь решить эту задачу: геодезические, сейсмологические, вулканологические.

Возможности геодезических методов хорошо пока- 
заны в публикациях Ю.О. Кузьмина [Kuzmin, 2004]. Выявлены приуроченные к зонам разломов различных типов и порядков вертикальные и горизонтальные суперинтенсивные локальные аномалии и деформации. Их возникновение обусловлено изменениями параметров изначально нагруженной среды внутри самих разломных зон (модули жесткости, коэффициенты трения и др.), что, согласно теории механических колебаний, выводит зону разлома из состояния динамического равновесия. Источником нарушения кинематического состояния могут быть волновые процессы. Прямыми геодезическими измерениями установлено существование двух типов волн: «межразломных» и «внутриразломных», вызывающих активизацию разломов, и разработана феноменологическая модель формирования автоволновых деформационных процессов [Kuz'$\min , 2012]$.

Очень важны современные методы GPS-геодезии для характеристик деформаций и подвижек в крупных разломных зонах. При целенаправленном установлении пунктов наблюдений вкрест исследуемых разломных зон можно получить важные количественные характеристики деформации межблоковых пространств, объединяющих широкие области динамического влияния разломов. В этом отношении интересные результаты получены В.А. Саньковым и др. [San'kov et al., 2005] при систематических наблюдениях за изменениями маркеров и движениями земной поверхности в сейсмических зонах Монголии.

Для оценки активизации разломов в реальном времени наиболее представительными являются сейсмические данные. Согласно определениям многих исследователей [Nikonov, 1995; Nesmeyanov, 2004; Trifonov, 1985; Sherman et al., 2005d; Fukuyama, Ikeda, 2002], именно сейсмические события, контролируемые разломами, особенно в масштабах реального времени, несут самую достоверную и конкретно привязанную ко времени информацию об их (разломов) активизации. Необходимо принять во внимание и то обстоятельство, что сейсмический процесс в границах областей динамического влияния разломов протекает неравномерно в пространстве и во времени [Sherman et al., 2004]. Довольно часто, даже в отдельные годы, сейсмически активные разломы характеризуются очень низкой или, наоборот, высокой сейсмичностью. То же относится к разным сегментам протяженных активных разломов. В это же время многочисленные разноранговые группы геологически закартированных разрывов остаются асейсмичными в границах сейсмической области. Для понимания закономерностей достаточно сложной и во многом не ясной избирательной современной активизации разноранговых и разновозрастных разломов было предложено провести их классификацию и ранжирование по количественному индексу сейсмической активности (КИСА), под которым понимается число сейсмических событий определенных энергетических классов, приходящихся на еди- ницу длины разлома при принятой ширине области его динамического влияния за заданный промежуток времени [Sherman et al., 2005d]. В цифровом значении КИСА однозначно позволяет отделить активные разломы от неактивных на современном этапе развития по данным инструментальных наблюдений за сейсмическим процессом. КИСА помогает ранжировать разломы по относительной кинематической активности за любые заданные интервалы времени. Эндогенные источники развития разломов и генетически связанной с ними сейсмичности в задаваемые, с геологической точки зрения мгновенные, интервалы времени остаются пространственно и энергетически стабильными. Следовательно, пространственно-временные закономерности в возбуждении активизации разломов в интервалах реального времени следует искать в энергетически слабых, но достаточных для нарушения метастабильного состояния разломно-блоковой среды литосферы триггерных механизмах. Ими могут являться волновые процессы в литосфере Земли, в частности деформационные волны [Ulomov, 1993; Bykov, 2005; Sherman, 2009b; Kuz'min, 2012; Gorbunova, Sherman, 2012; Stepashko, 2011]. Заметим, что короткопериодная активизация разломов, как единичных, так и их ансамблей, не является процессом, типичным для современного этапа эволюции. Волновые процессы - характерное явление для Земли, и в той или иной степени они всегда воздействовали на геодинамические процессы [Khain, Khalilov, 2009; Petrov, 2007].

Системы разломов определяют разломно-блоковую структуру литосферы. Селективная активизация даже одного ограничивающего блок разлома может быть достаточной для нарушения динамического равновесия всего блока. Если же в процесс активизации вовлекаются ансамбли разломов, в нестабильное состояние может быть вовлечена система сближенных блоковых структур. При высокой короткопериодной частоте такого процесса, характерного для континентальных сейсмических зон, фиксируются землетрясения различной силы не только в межблоковых разломах, но и во внутриблоковых разрывах более низких рангов (см. рис. 8) [Sherman et al., 1996]. Следовательно, короткопериодная в реальном времени активизация разломно-блоковых структур литосферы может представлять собой значимый геодинамический процесс. Он происходит в регионах современной тектонической активизации (например, в Байкальской и ВосточноАфриканской рифтовых системах) и, главным образом, во всех современных сейсмических зонах Земли. Можно ли изучать процесс активизации разломноблоковых структур литосферы в отрыве от изучения геодинамики развития и эволюции отдельных тектонических зон Земли? Скорее всего можно, поскольку площадное расширение применения и развития методов GPS-геодезии приводит к построению средне- и крупномасштабных карт кинематической подвижности разломно-блоковой структуры земной коры и ли- 
тосферы в целом, выделению относительно стабильных и мобильных в реальном времени зон на земной поверхности с соответственно различной степенью геоэкологической опасности в широком использовании этого понятия.

Известны ли иные способы формирования блоковых структур в природных средах? Очень кратко о возможности формирования некоторых геологических структур при моделировании в волновых полях механических напряжений. Подобные экспериментальные работы, к сожалению без применения условий подобия, были проведены Л.М. Плотниковым [Plotnikov, 1985]. Используя увлажненную смесь песка и глины в полях ультразвука, автор получал качественное разделение смеси на слои песка и глины с образованием резких границ между слоями. Суперпозицией различно ориентированных полей плоских стоячих волн экспериментатор получал более сложные результирующие поля, например цилиндрические тела с сечениями, соответствующими какой-то из изоамплитуд результирующего поля. В моделях были воспроизведены хорошо известные петрографам текстуры «карандашного» гнейса, образуемые следами изоамплитудных поверхностей результирующих полей, а границы последних отражают «распространенные в природе правильные сетки и решетки разрывных нарушений» (см. рис. 3) [Plotnikov, 1985, p. 116].

Не менее значимы для понимания возникновения волновых процессов в литосфере и земной коре расчеты А.В. Лукьянова [Lukyanov, 1985a], выполненные на основе экспериментальных и природных геологических данных. Им показано, что некоторые энергоемкие геологические процессы не лишены автоколебательных систем. В частности, они зарождаются при плавлении литосферы во время переноса тепла через простейшую однородную модель литосферы. Особенно сложное физическое состояние возникает тогда, когда расплав образуется на границе двух сред и его состав неоднороден. Градиент температуры плавления в локальной области формирования расплава (очага) может оказаться ниже градиента температур на этой глубине в литосфере. Расплав окажется перегретым на уровне своего основания и переохлажденным у верхней границы. Плавление у нижней границы, кристаллизация у верхней и соответствующее перемещение расплава вниз будут неизбежным результатом такой ситуации, то есть возникнет зонная плавка с движением расплава навстречу тепловому потоку. Смена двух типов теплопередачи приводит к возникновению автоколебательной системы, на первой стадии которой расплав мигрирует вниз, а на второй - вверх. В зависимости от направления миграции расплава изменяется тенденция эволюции его состава и возникает ряд следствий, в том числе и автоколебательные системы [Lukyanov, 1985b].

Таким образом, протекающие геологические процессы в определенных условиях способны генериро- вать собственные колебания. Обнаружить эти колебания не всегда просто и, тем более, нелегко объяснить их генетическую природу.

В курсе изложения проблемы волновых процессов важно вновь обратиться к уже цитированной работе Ю.О. Кузьмина [Kuz’min, 2012], в которой на уровне современных физических представлений рассматриваются возможности формирования деформационных автоволн в разломных зонах. Благодаря комплексной программе изучения современных движений земной коры в нефтегазоносных бассейнах древней докембрийской Русской платформы, ряде предгорных и межгорных прогибов складчатых областей были установлены пункты наблюдений с совершенно идентичными задачами и измерительными системами. Итоговые параметры измерительных систем на геодинамических полигонах, расположенных в платформенных, асейсмичных районах, оказались идентичными аналогичным параметрам в сейсмоактивных областях (рис. 13). Выявлены приуроченные к зонам разломов различных типов и порядков вертикальные и горизонтальные интенсивные локальные аномалии. Они высокоамплитудны (50-70 мм/год), короткопериодичны (0.1-1.0 год), пространственно локализованы (0.1-1.0 км), обладают пульсационной и знакопеременной направленностью. Относительные изменения среднегодовых скоростей для них чрезвычайно высоки и составляют величины порядка (2-7)·10 $10^{-5}$ год. Подобные интенсивные движения в приразломных областях Ю.О. Кузьмин [Kuzmin, 2004] назвал суперинтенсивными деформациями земной поверхности в зонах разломов. Им же предложена классификация основных типов аномального изменения современных движений земной поверхности в пределах зон или областей активного динамического влияния разломов. Совершенно независимым геодезическим методом установлена высокая современная подвижность крыльев разломов в регионах с разными современными типами и интенсивностью движений земной коры. Подобный «высокочастотный» короткопериодный спектр движений трудно объясним динамикой астеносферных процессов. С.И. Шерман [Sherman, 2009a] короткопериодную активизацию разрывов, замеченную Ю.О. Кузьминым [Kuzmin, 2004], связал с воздействием деформационных волн. Ю.О. Кузьмин [Kuz’min, 2012] на основе анализа среднегодовой трендовой скорости деформаций на значительных площадях, где были проведены наблюдения, считает, что зафиксированные суперинтенсивные деформации разломных зон представляют собой параметрически индуцированные тектонические деформации геологической среды. Фиксируемые флуктуации деформаций, по аргументам Ю.О. Кузьмина [Kuz’min, 2012, p. 6], имеют «ярко выраженный автоколебательный характер, так как их характеристики определяются свойствами среды внутри самих разломных зон». Многие из этих свойств невосстанавливаемые, не дают объяснения периодической активиза- 

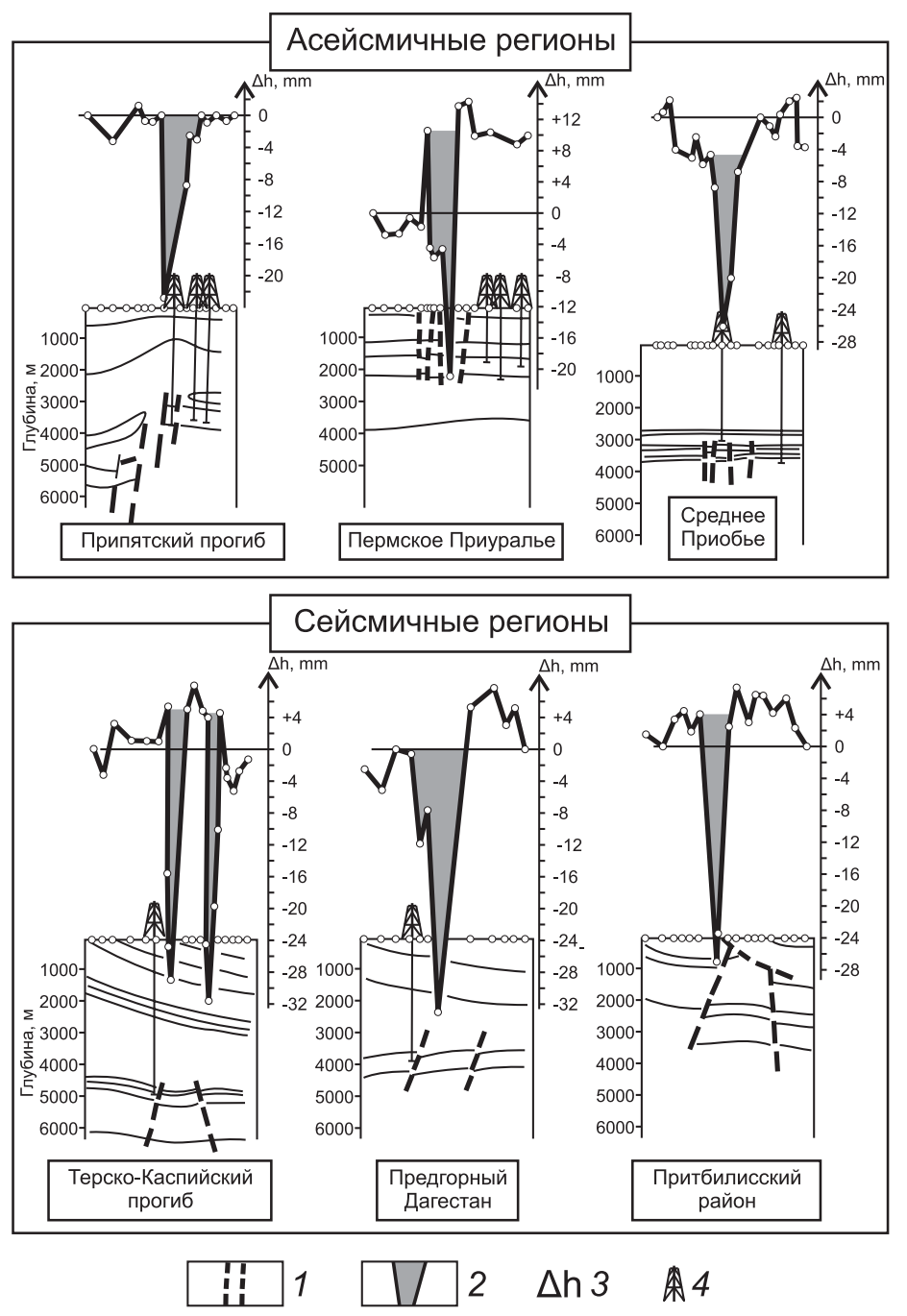

Рис. 13. Локальные аномалии движений земной поверхности в зонах разломов в различных регионах [Кuzтin, 2004]. 1 - зоны разрывных нарушений; 2 - зоны аномальных вертикальных движений; 3 - амплитуды современных вертикальных движений земной поверхности; 4 - пробуренные скважины.

Fig. 13. Local anomalies in movements of the Earth's surface in fault zones in different regions [Kuzmin, 2004]. 1 - fault zones; 2 - zones of anomalous vertical movements; 3 - amplitudes of recent vertical movements of the Earth's surface; 4 - drilled wells.

ции ансамбля сейсмоактивных разломов, но объясняют важную сторону сейсмического процесса - параметрическое возбуждение разломов малыми воздействиями. Это же свойство - возбуждение разломов деформационными волнами как триггерными механизмами - считается ведущим в тектонофизической модели континентальной сейсмической зоны [Sherman, 2009b].

Дальнейшие разработки физической сущности и закономерностей сейсмического процесса в сейсмических зонах литосферы внесут уточнения в изложенные непринципиальные расхождения исследователей о природе волн, возбуждающих разломы литосферы в короткопериодные интервалы времени. В наступивший век все больше и больше фактов свидетельствуют о необходимости более глубокого изучения многих геолого-геофизических процессов в литосфере, а осо- бенно в земной коре [Goldin, 2004; Plekhov, Panteleev, 2008]. Многие из современных процессов, контролируемых разломами, необходимо рассматривать, анализировать и прогнозировать во временных границах шкалы реального времени и, в пределах возможного, на количественной основе. Это же относится и к проблемам современной короткопериодной активизации блоковых структур литосферы. Таково требование современной быстро развивающейся социальной среды.

\section{7. ОБЩИЕ ТЕКТОНОФИЗИЧЕСКИЕ ЗАКОНОМЕРНОСТИ ДЕСТРУКЦИИ ЛИТОСФЕРЫ}

Изложенные данные как продолжение многих близких по направленности исследований работ, например М.А. Садовский и др. [Sadovsky et al., 1987], а также 

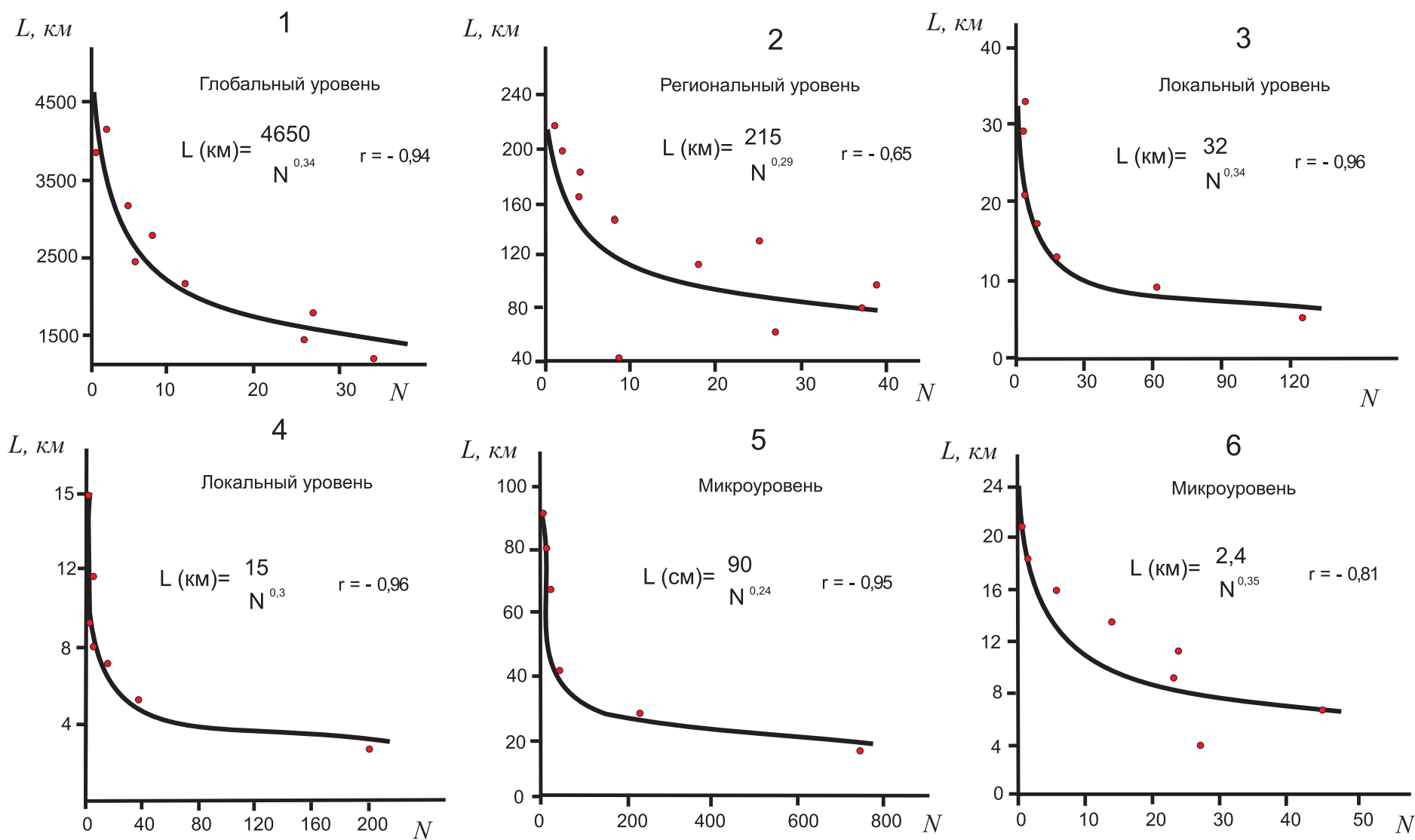

Рис. 14. Соотношения поперечных размеров разноранговых блоков $\mathrm{L}_{\mathrm{bl}}$ и их количества $\mathrm{N}_{\mathrm{bl}}$ [Sherman et al., 1999].

Fig. 14. The ratio of transverse dimensions of blocks of different ranks, $\mathrm{L}_{\mathrm{bl}}$ and their number, $\mathrm{N}_{\mathrm{bl}}$ [Sherman et al., 1999].

Г.А. Соболев [Sobolev, 2002; Sobolev, Asatryan, 1990]; С.В. Гольдин [Goldin, 2004]; В.С. Пономарев и др. [Ponomarev et al., 1995], С.Н. Журков и др. [Zhurkov et $a l ., 1983]$ в сочетании с последующими исследованиями С.И. Шермана и др. [Sherman et al., 1999] в регионах с различными режимами геодинамического развития позволили установить зависимость попереч-

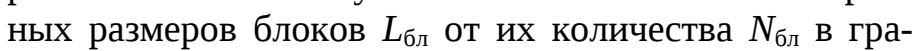
ницах определенных площадей, которая описывается общим уравнением:

$$
L_{\text {бл }}=f\left(N_{\text {бл }}\right) .
$$

Оно получено на основе анализа частных зависимостей

$$
L_{\mathrm{i} б л}=f\left(N_{\text {ібл }}\right)
$$

(рис. 14). Последовательное увеличение масштабов подчеркивает принципиальное строение разноранговой блоковой структуры. Фактически структура блоков и межблоковых пространств, изученная в разных масштабах и с разной степенью детальности, остается одинаковой в своих главных чертах.

Идентичность всех полученных частных уравнений указывает на общую закономерность блоковой делимости литосферы, не зависящую от геодинамического режима развития отдельных регионов и описываемую уравнением:

$$
\bar{L}_{б л}=A / N_{б л}{ }^{c},
$$

при относительно постоянном с $\approx 0.22-0.35$ и вариациях свободного члена А, зависящих от изменения масштабов выборки и указывающих на дискретность распределения средних размеров блоков литосферы [Sherman, 2002]. Эта закономерность наиболее обоснована для блоковой тектоники преимущественно земной коры и отражает ее делимость на втором или третьем масштабно-временном уровне практически для всех рангов разломов (рис. 15). В целом во временной последовательности формируется двухуровневая масштабно-временная вертикальная зональность интенсивности разломно-блоковой делимости (деструкции) литосферы (рис. 16).

В более ранних работах [Sherman, 1977; Sherman et $a l ., 1992]$ было показано, что разломная делимость литосферы описывается уравнением:

$$
L=\mathrm{a} / N^{b},
$$




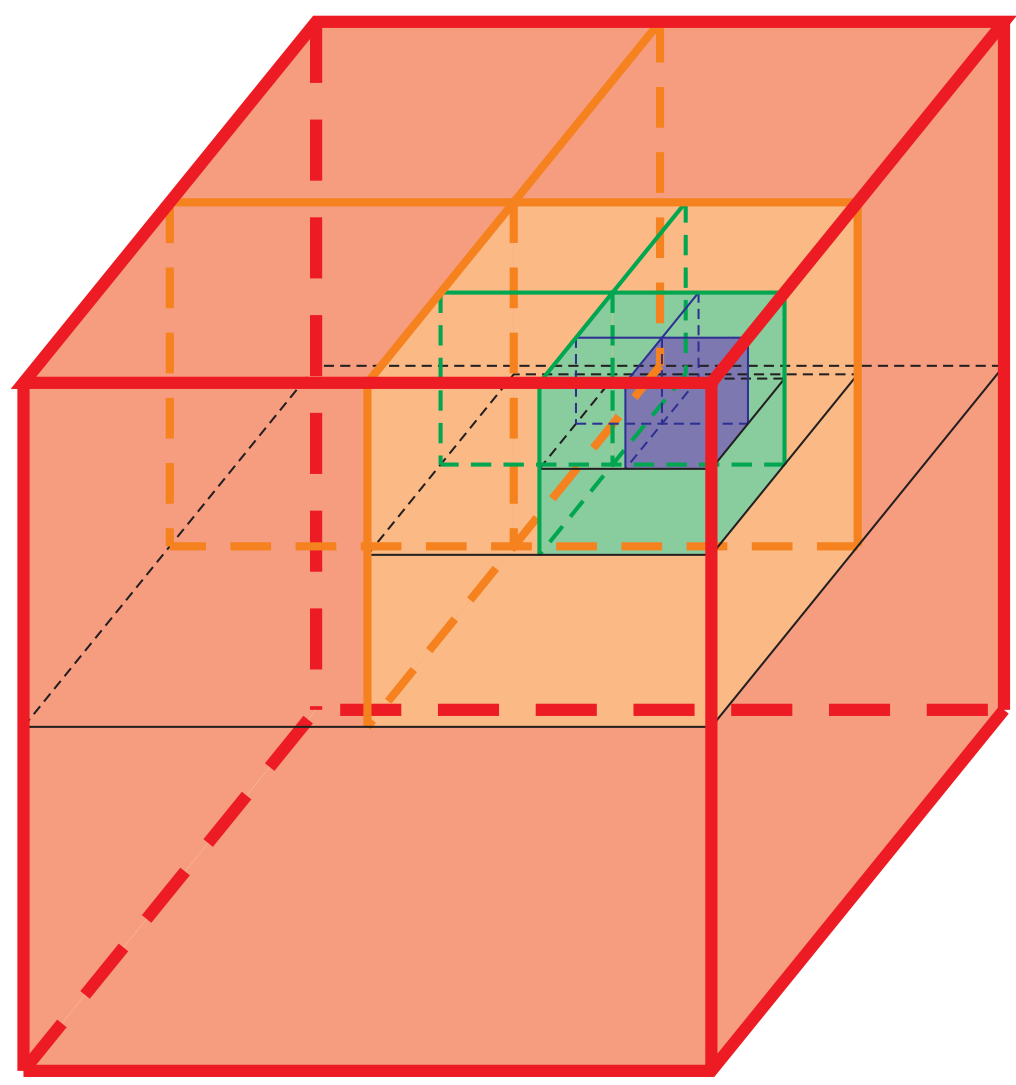

Рис. 15. Принципиальный характер внутриблоковой делимости литосферы на втором масштабно-временном уровне.

Fig. 15. The fundamental pattern of intra-block divisibility of the lithosphere at the second scale-time level.

в котором $L$ - длина разломов; $N$ - их количество; $a-$ коэффициент пропорциональности, зависящий от максимальных длин разломов, участвующих в выборке; $b$ - коэффициент пропорциональности, определяемый физическими свойствами горных пород, скоростью деформирования среды и равный 0.4. В «скрытой» форме он отражает вязкость земной коры или литосферы в целом. Полученное соотношение позволяет сделать вывод, что при формировании сетки разломов, т.е. при мега- и макроразрушении горных пород в естественных условиях, независимо от степени тектонической активизации проявляются некоторые общие закономерности дробления твердых тел.

Подобную задачу - закономерности дробления твердых тел - много лет тому назад независимо друг от друга математически рассмотрели А.Н. Колмогоров [Kolmogorov, 1941] и А.Ф. Филиппов [Filippov, 1961], которые показали, что при дроблении твердых тел распределение

$$
\lg N=f(\lg L) \text {, }
$$

где $L$ - произвольная характеристика размера образца, прямолинейно в координатах $\lg L$ и $\lg N$. Последнее означает подобие явления разрушения в широком диапазоне изменения величин, т.е. свойство автомодель- ности процесса разрушения. В это свойство вписываются установленные эмпирические зависимости, охватывающие более крупные по масштабу объекты - разломы земной коры и, частично, разломы верхней хрупкой части литосферы.

Обычно при исследовании механизма образования разломов, особенно мелких, используются представления механики простейшей сплошной среды, каковой является идеально упругое тело Гука. Возможно, такой подход справедлив при анализе отдельных дислокаций. В региональном же и более мелком масштабах динамику развития сетки разломов в отличие от одиночной дислокации необходимо рассматривать, опираясь на поведение материала земной коры как упруговязкого тела, поскольку обобщенные реологические свойства земной коры и литосферы в целом отличаются от свойств отдельных горных пород и приближаются к свойствам максвелловского тела [Sherman, 1977, 2002].

Сопоставляя уравнения (7) (8) делимости верхней хрупкой части литосферы, в которых $a$ и $A$ отражают вариации свободных членов, зависящие от максимальных длин участвующих в выборке разломов или средних поперечных размеров блоков; $b$ и $c-$ коэффициенты пропорциональности, причем $b$ относительно постоянен и равен 0.4 , а $c \approx 0.22-0.35$, мы обращаем вни- 


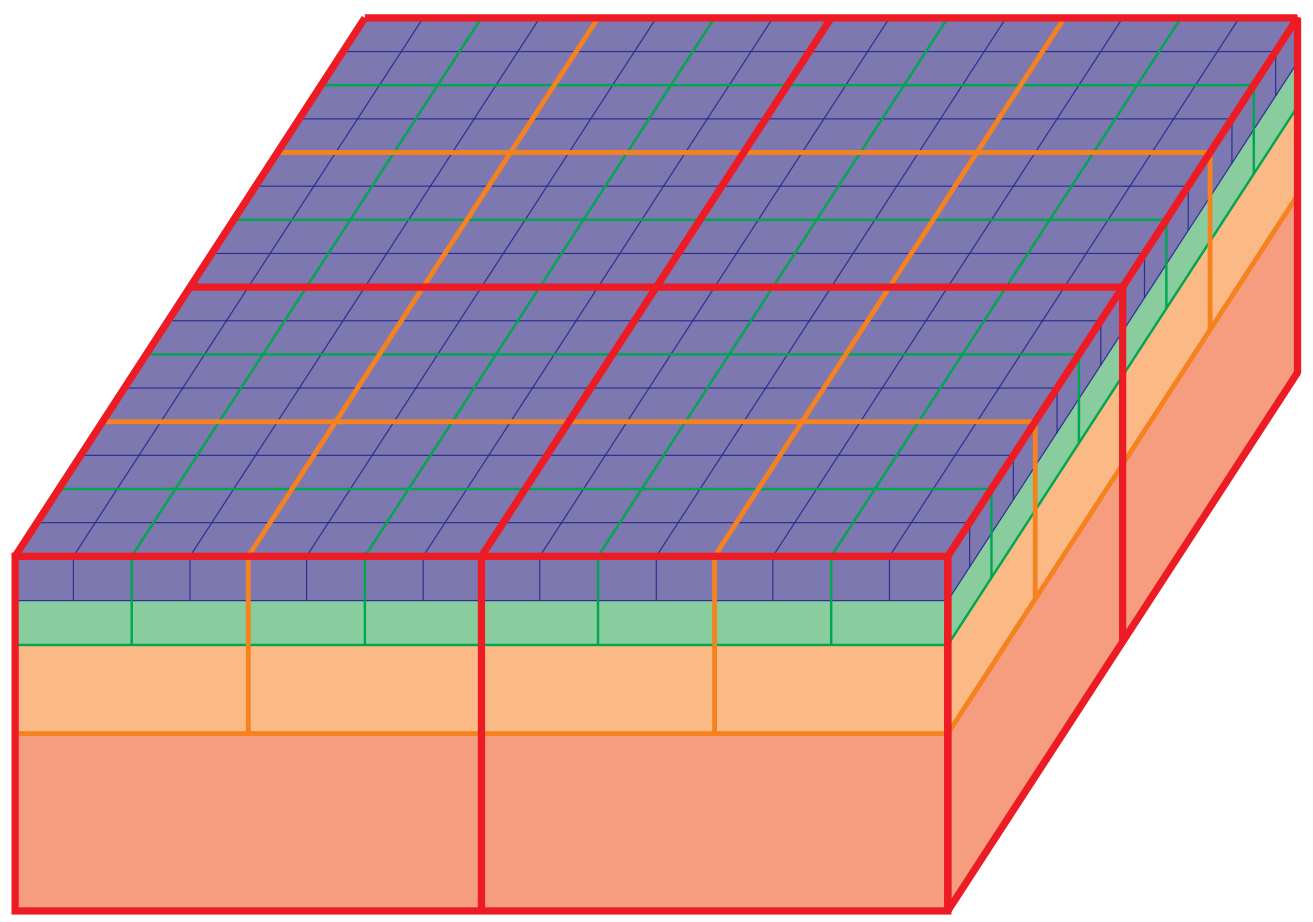

Рис. 16. Двухуровневая масштабно-временная вертикальная зональность интенсивности разломно-блоковой делимости (деструкции) литосферы.

Fig. 16. The two-level scale-time vertical zonation of the intensity of fault-block divisibility/ destruction of the lithosphere.

мание на их математическое сходство и общность физического смысла. Сходство уравнений для блоковой и разломной делимости литосферы позволяет считать, что в основе ее деструкции, независимо от конкретных форм ее выражения и описания, лежат одни и те же законы. Собственно блоковую тектонику можно рассматривать как предел разломной деструкции литосферы на соответствующих иерархических уровнях. Таким образом, деструкция литосферы при разных геодинамических режимах и полях напряжений может быть описана общим математическим выражением:

$$
L=A / N^{c},
$$

где $L$ - размер разрывных или блоковых структур; $N$ их количество; $A$ - свободный член, зависящий от размеров структур в выборке; $c$ - степенной показатель, изменяющийся от 0.4 до 0.22 при переходе от разломов к блокам. Можно считать, что уравнение (10) является математической закономерностью деструкции хрупкой части литосферы при действии региональных и трансрегиональных напряжений. Вариации коэффициента $A$ сглаживают и отражают разные ранги (масштабы) участвующих в выборке линейных параметров, а $c$ - отражает обобщенные физические свойства литосферы, главными из которых можно считать ее прочность, в том числе реологические характеристики, и горизонтальную расслоенность. Статистическое распределение совокупностей блоков или разломов по размерам закономерно и предсказуемо, они образуют изменяющиеся иерархические ряды с некоторыми модами преимущественных размеров. Они формируют системы с разной степенью подвижности и межблоковой проницаемости [Gufeld et al., 2011]. Отдельно взятые совокупности блоков или разломов фрактальны.

Самоподобный процесс деструкции литосферы отражается и в синхронных с ней проявлениях сейсмичности: законы Гутенберга-Рихтера и Омори для землетрясений [Gutenberg, Richter, 1955; Sherman, 2002; Ouillon, Sornette, 2005]. Здесь особенно важно обратить внимание на двухуровневую масштабно-временную блоковую делимость литосферы. Предварительные исследования показывают, что очаги сильных, часто, к сожалению, катастрофических, землетрясений мира контролируются крупными межблоковыми разломами, относящимися к первому (или второму, как крайний случай), первично сформированному глобальному масштабно-временному уровню разломно-блоковой делимости литосферы. Именно этот однотипно сформированный ансамбль крупных генеральных и трансрегиональных разломов контролирует в своих зонах локализацию сильных землетрясений. Кинематика характеризуемых разломов на современном этапе геодинамического состояния литосферы определяется движениями ограничивающих их блоков, зависящими от трех главных из многих не менее важных энергетических источников и прочностных характеристик: подлитосферных движений в астеносфере, прочности 
межблоковой среды, определяющей, прежде всего, прочностные свойства контактов блоков, энергии триггерных механизмов, способствующих возбуждению метастабильного состояния разломно-блоковой среды литосферы в конкретных случаях.

Разломы - сложные геологические тела. Повсеместное распространение трещин и разноранговых разломов в коренных выходах литифицированных, изверженных и метаморфических пород на земной поверхности и распространение разноранговых разрывов на различные глубины составляют одну из основных проблем в их изучении, которая усложняется при переходе на другой структурно-геодинамический уровень исследований - изучение закономерностей разломноблоковой делимости литосферы.

\section{8. ЗАКЛЮЧЕНИЕ}

Литосфера является базой всех геолого-геофизических исследований, направленных на изучение закономерностей развития основных структур Земли и контролируемых ими процессов. Одним из них является разломообразование в литосфере - процесс продолжающейся с архея до настоящего времени своеобразного вида деструкции и в то же время эволюционного развития литосферы. С ним связано и формирование крупных геотектонических провинций, систем и зон (авлакогены и рифтовые системы Земли, сейсмические зоны и отдельные месторождения, некоторые группы вулканов и другие, чаще всего локальные социально полезные (выходы термальных и минеральных источников) или катастрофические явления (нарушения трубопроводов и других сетей и социальных объектов). Разностороннее знание законов развития такого охватывающего всю верхнюю оболочку Земли процесса ее деструкции важно в теории и полезно в практической деятельности.

В теоретическом плане в статье показана двухуровневая масштабно-временная или, что аналогично, пространственно-временная, разломно-блоковая делимость литосферы. Подобный подход в масштабногенетическом отношении позволяет разделить крупные разломы Земли в самом начальном периоде их зарождения и развития на крупнейшие разновидности, заложенные как пограничные «структуры» конвекционных ячей, завершающих архейскую, возможно, архейско-протерозойскую, стадию становления литосферы. С этого раннего и практически вплоть до современного периода эволюционного развития литосферы такие разломы «созревали», во многом трансформировались, но на протяжении всего постархейско-протерозойского периода оставались крупнейшими линеаментами Земли. Они способствовали делению нашей планеты на прообраз современных континентов, а их - на крупные плиты и блоки. В современный этап многие разломы первого масштабно-временного уровня и дополнительно некоторые позднее сформированные межблоковые разломы играют главную роль в контролировании крупнейших наиболее сильных землетрясений мира. Не случайно после Великого японского землетрясения Tohoku в марте 2011 г., как сообщил 29 октября 2012 г. телеканал NHK, японские ученые по заданию правительства займутся изучением исторических свидетельств о мощных землетрясениях прошлого и тщательно изучат исторические документы и другие свидетельства о мегаземлетрясениях прошлого. Именно исторических сведений в настоящий период недостаточно для изучения пространственно-временной локализации сильных землетрясений в зонно-блоковой области крупных активных на современном этапе межблоковых разломов и границ плит.

Разломы второго масштабно-временного уровня образуют всю ориентированную и организованную в литосфере разломно-блоковую структуру, ее определяющую роль и значимость в контролировании ряда процессов, вариаций геолого-геофизических полей, придающих верхнему слою литосферы особое физическое состояние - метастабильное. Оно во многом «ответственно» и за различные катастрофические явления, детально изучаемые современными методами. На очереди - познание закона эволюции деструкции литосферы Земли в целом. Необходимо ввести в обсуждение вариации реологических свойств вертикального разреза литосферы, влияния фактора времени на реологические и прочностные свойства, наконец, первичную неоднородность среды литосферы в сочетании с современными геодинамическими процессами. Проблема решаемая, ее практическая значимость несомненна.

\section{9. БЛАГОДАРНОСТИ}

Автор благодарит Ю.Г. Гатинского за продуктивные советы и замечания, учтенные при подготовке рукописи, В.А. Санькова - за внимание к исследованиям автора и постоянные результативные дискуссии.

Исследования выполнены при поддержке РФФИ (грант 12-05-91161-ГФЕН_а), проектов ОНЗ РАН 7.7; Президиума РАН № 4.8; ГК 14.790.11.0411.

\section{0. ЛИТЕРАТУРА}

Adushkin V.V., Spivak A.A., Loktev D.N., 1997. Diagnosis of rock massifs in the Mayak territory from results obtained by monitoring of relaxation processes. Voprosy radiatsionnoy bezopasnosti 1, 18-30 (in Russian) [Адушкин В.В., Спивак А.А., Локтев Д.Н. Диагностика массивов горных пород территории ПО «Маяк» по результатам мониторинга релаксационных процессов // Вопросы радиационной безопасности. 1997. № 1. С. 18-30]. 
Belousov T.P., Kurtasov S.V., Mukhamediev Sh.A., 1997. Divisibility of the Earth's Crust and Paleostresses in Seismically Active and Oil-and-Gas-Bearing Regions of the Earth. UIPE RAS, Moscow, 324 p. (in Russian) [Белоусов Т.П., Куртасов С.В., Мухамедиев Ш.А. Делимость земной коры и палеонапряжения в сейсмоактивных и нефтегазоносных регионах Земли. М.: ОИФЗ РАН, 1997. 324 с.].

Bornyakov S.A., Sherman S.I., 2006. From nonstationary fault models to fracture dissipative structures of the lithosphere. In: Active Tectonic Areas in the Recent and Ancient History of the Earth. Proceedings of the $39^{\text {th }}$ Tectonic Conference. Publishing House of the Inter-Agency Tectonic Commission, Moscow, V. 2, p. 384-387 (in Russian) [Борняков С.А., Шерман С.И. От нестационарных моделей разломов к разрывным диссипативным структурам литосферы // Области активного тектогенеза в современной и древней истории Земли. М.: Межвед. тектон. комитет, 2006. Т. 2. C. 384-387].

Bykov V.G., 2005. Strain waves in the Earth: theory, field data, and models. Russian Geology and Geophysics 46 (11), $1176-1190$.

Chebanenko I.I., 1963. Basic Regularities and Problems of Faulting of the Earth’s Crust. AN USSR, Kiev, 154 p. (in Russian) [Чебаненко И.И. Основные закономерности разломной тектоники земной коры и ее проблемы. Киев: АН УССР, 1963. 154 с.].

Chernyshov S.N., 1983. Fractures in Rocks. Nauka, Moscow, 240 p. (in Russian) [Чернышов C.Н. Трещины горных пород. М.: Наука, 1983. 240 с.].

Fault Map of the USSR and adjacent countries (scale 1: 2500000), 1977 (in Russian) [Карта разломов территории СССР и сопредельных стран (масштаб 1 : 2500000). 1977].

Filippov A.F., 1961. On the distribution of particle by sizes during crushing // The Theory of Probability and Its Applications VI (3), 14-19 (in Russian) [Филиппов А.Ф. О распределении размеров частиц при дроблении // Теория вероятностей и ее применения. М.: Изд-во АН СССР, 1962. Т. VI. Вып. 3. С. 14-19].

Fukuyama E., Ikeda R., 2002. Proceedings of the international Workshop on the Physics of Active Fault. National Research Institute for Science and Disaster Prevention, Japan, Tokio, 382 p.

Gatinsky Yu.G., Rundquist D.V., 2004. Geodynamics of Eurasia: plate tectonics and block tectonics. Geotectonics 38 (1), $1-16$.

Gatinsky Yu.G., Rundquist D.V., 2009. Zones of catastrophic earthquakes of Central Asia: Geodynamics and seismic energy. Russian Journal of Earth Sciences 11, ES1001. http://dx.doi.org/10.2205/2009ES000326.

Gatinsky Y., Rundquist D., Vladova G., Prokhorova T., 2011. Up-to-date geodynamics and seismicity of Central Asia. International Journal of Geosciences 2 (1), 1-12. http://dx.doi.org/10.4236/ijg.2011.21001.

Gatinsky Yu.G., Rundkvist D.V., Vladova G.L., Prokhorova T.V., 2011b. Seismic and geodynamic monitoring the main power plants in Russia and CIS. In: Extreme natural phenomena and disasters. Uranium Geology, geo-ecology, and glaciology. IPE RAS, Moscow, V. II. 13-27 (in Russian) [Гатинский Ю.Г., Рундквист Д.В., Владова Г.Л., Прохорова Т.В. Сейсмо-геодинамический мониторинг главнейших энергетических объектов России и ближнего зарубежья // Экстремальные природные явления и катастрофы. Геология урана, геоэкология, гляциология. М.: ИФЗ РАН, 2011б. T. II. C. 13-27].

Gatinsky Yu.G., Rundquist D.V., Vladova G.L., Prokhorova T.V., Romanyuk T.V., 2008. Block structure and geodynamics of continental lithosphere in plate boundaries. Bulletin of Kamchatka regional association "Educational-Scientific Center". Earth Sciences 1 (11), 32-47.

Gatinsky Yu.G., Vladova G.L., Prokhorova T.V., Rundkvist D.V., 2011a. Geodynamics of Central Asia and forecasting of catastrophic earthquake. Prostranstvo i Vremya 3 (5), 124-134 (in Russian) [Гатинский Ю.Г., Владова Г.Л., Прохорова Т.В., Рундквист Д.В. Геодинамика Центральной Азии и прогноз катастрофических землетрясений // Пространство и время. 2011а. Т. 3. № 5. С. 124-134].

Goldin S.V., 2002. Lithosphere destruction and physical mesomechanics. Physical Mesomechanics Journal 5 (5-6), 5-20.

Goldin S.V., 2004. Dilatancy, repacking, and earthquakes. Izvestiya, Physics of the Solid Earth 40 (10), 817-832.

Gorbunova E.A., Sherman S.I., 2012. Slow deformation waves in the lithosphere: registration, parameters, and geodynamic analysis (Central Asia). Russian Journal of Pacific Geology 6 (1), 13-20. http://dx.doi.org/10.1134/S181971401 201006X.

Gufeld I.L., Matveeva M.I., Novoselov O.N., 2011. Why we cannot predict strong earthquakes in the Earth's crust. Geodynamics \& Tectonophysics 2 (4), 378-415. http://dx.doi.org/10.5800/GT-2011-2-4-0051.

Gutenberg B., Richter C.F., 1955. Magnitude and energy of earthquakes. Nature 176 (4486), 795. http://dx.doi.org/10.1038/ $176795 \mathrm{a} 0$.

Gzovsky M.V., 1971. Mathematics in Geotectonics. Nedra, Moscow, 240 p. (in Russian) [Гзовский М.В. Математика в геотектонике. М.: Недра, 1971. 240 с.].

Gzovsky M.V., 1975. Fundamentals of Tectonophysics. Nauka, Moscow, 536 p. (in Russian) [Гзовский М.В. Основы тектонофизики. М.: Наука, 1975. 536 с.].

Jin S., Park P.-H., Zhu W., 2007. Micro-plate tectonics and kinematics in Northeast Asia inferred from a dense set of GPS observations. Earth and Planetary Science Letters 257 (3-4), 486-496. http://dx.doi.org/10.1016/j.epsl.2007.03.011.

Khain V.E., 1981. International tectonic map of the World (Scale 1:15000000). USSR Academy of Sciences, Commission on Geological Map of the World, Moscow. 
Khain V.E., Khalilov E.N., 2009. Cyclicity of Geodynamic Processes: Possible Nature. Nauchny Mir, Moscow, 520 p. (in Russian) [Хаин B.Е., Халилов Э.Н. Цикличность геодинамических процессов: ее возможная природа. М.: Научный мир, 2009. 520 с.].

Kocharyan G.G., 2010. Fault zone as a nonlinear mechanic system. Fizicheskaya Mezomechanika 13 (special issue), 5-17 (in Russian) [Кочарян Г.Г. Разломная зона как нелинейная механическая система // Физическая мезомеханика. 2010. T. 13. Спец. выпуск. С. 5-17].

Kocharyan G.G., Kishkina S.B., Ostapchuk A.A., 2010. Seismic picture of a fault zone. What can be gained from the analysis of fine patterns of spatial distribution of weak earthquake centers? Geodynamics \& Tectonophysics 1 (4), 419-440. http://dx.doi.org/10.5800/GT-2010-1-4-0027.

Kocharyan G.G., Kishkina S.B., Ostapchuk A.A., 2011. Seismogenic width of a fault zone. Doklady Earth Sciences 437 (1), 412-415. http://dx.doi.org/10.1134/S1028334X11030147.

Kocharyan G.G., Spivak A.A., 2003. Dynamics of Deformation Of Block Rock Masses. ICC Akademkniga, Moscow, 423 p. (in Russian) [Кочарян Г.Г., Спивак А.А. Динамика деформирования блочных массивов горных пород. М.: ИКЦ «Академкнига», 2003. 423 с.].

Kolmogorov A.N., 1941. On the log-normal distribution of particles during crushing // Doklady AN SSSR 31 (2), $99-101$ (in Russian) [Колмогоров А.Н. О логарифмически-нормальном законе распределения частиц при дроблении // Доклады АН СССР. 1941. Т. 31. № 2. С. 99-101].

Kostyuchenko V.N., Kocharyan G.G., Pavlov D.V., 2002. Strain characteristics of interblock gaps of different scales. Physical Mesomechanics Journal 5 (5-6), 23-42.

Krasny L.I., 1967. Geoblocks. Geotektonika 5, 103-120 (in Russian) [Красный Л.И. Геоблоки // Геотектоника. 1967. № 5. C. 103-120].

Krasny L.I., 1984. Global System of Geoblocks. Nedra, Moscow, 224 p. (in Russian) [Красный Л.И. Глобальная система геоблоков. М.: Недра, 1984. 224 с.].

Kuzmin Yu.O., 2004. Recent geodynamics of fault zones. Izvestiya, Physics of the Solid Earth 40 (10), 868-883.

Kuz'min Yu.O., 2012. Deformation autowaves in fault zones. Izvestiya, Physics of the Solid Earth 48 (1), 1-16. http://dx. doi.org/10.1134/S1069351312010089.

Liu M., Yang Y., Shen Z., Wang S., Wang M., Wan Y., 2007. Active tectonics and intracontinental earthquakes in China: the kinematics and geodynamics. Geological Society of America Special Paper 425, 299-318. http://dx.doi.org/10.1130/ 2007.2425(19).

Lukyanov A.V., 1985a. Natural oscillations in models of geological auto-oscillation systems. In: Experimental tectonics in theoretical and applied geology. Nauka, Moscow, p. 94-112 (in Russian) [Лукьянов А.В. Собственные колебания в моделях геологических автоколебательных систем // Экспериментальная тектоника в теоретической и прикладной геологии. М.: Наука, 1985а. С. 94-112].

Lukyanov A.V., 1985b. Problems of physics of tectonic processes. In: The future of Geological Science. Nauka, Moscow, p. 53-62 (in Russian) [Лукьянов А.В. Проблемы физики тектонических процессов // Будущее геологической науки. М.: Наука, 1985б. С. 53-62].

Makarov P.V., 2004. On the hierarchical nature of deformation and fracture of solids and media. Physical Mesomechanics Journal 7 (3-4), 21-29.

Makarov P.V., 2007. Evolutionary nature of structure formation in lithospheric material: universal principle for fractality of solids. Russian Geology and Geophysics 48 (7), 558-574. http://dx.doi.org/10.1016/j.rgg.2007.06.003.

Makarov P.V., 2011. Resonance structure and inelastic strain and defect localization in loaded media. Physical Mesomechanics 14 (5-6), 297-307. http://dx.doi.org/10.1016/j.physme.2011.12.008.

Makarov P.V., Smolin I.Yu., Stefanov Yu.P., Kuznetsov P.V., Trubitsin A.A., Trubitsina N.V., Voroshilov S.P., Voroshilov Ya.S., 2007. Nonlinear Geomechanics of Geomaterials and Geoenvironments. Geo Publishing House, Novosibirsk, 235 p. (in Russian) [Макаров П.В., Смолин И.Ю., Стефанов Ю.П., Кузнецов П.В., Трубицин А.А., Трубицина Н.В., Ворошилов С.П., Ворошилов Я.С. Нелинейная геомеханика геоматериалов и геосред. Новосибирск: Академическое издательство «Гео», 2007. 235 с.].

Mooddy D.D., Hill M.D., 1960. Shear tectonics. In: Problems of modern foreign tectonics. Mir, Moscow, p. $265-333$ (in Russian) [Мудди Д.Д., Хилл М.Д. Сдвиговая тектоника // Вопросы современной зарубежной тектоники. М.: Мир, 1960. С. 265-333].

Nesmeyanov S.A., 2004. Introduction to Engineering Geotectonics. Nauchny Mir, Moscow, 216 p. (in Russian) [Несмеянов С.А. Введение в инженерную геотектонику. М.: Научный мир, 2004. 216 с.].

Nicolis G., Prigozhin I., 1979. Self-organization in Non-equilibrium Systems. From Dissipative Structures to Order through Fluctuations. Mir, Moscow, 512 p. (in Russian) [Николис Г., Пригожин И. Самоорганизация в неравновесных системах. От диссипативных структур к упорядоченности через флуктуации. М.: Мир, 1979. 512 с.].

Nikonov A.A., 1995. Active faults: identification and problem of identification. Geоеcology 4, 16-27 (in Russian) [Никонов А.А. Активные разломы: определение и проблемы выделения // Геоэкология. 1995. № 4. С. 16-27].

Ouillon G., Sornette D., 2005. Magnitude-depended Omori law: Theory and empirical study. Journal of Geophysical Research 110 (4), 1-28. http://dx.doi.org/10.1029/2004JB003311.

Peive A.V., 1990. Selected Works. Deep Faults and Their Role in the Structure and Development of the Earth's Crust. Nauka, 
Moscow, 352 p. (in Russian) [Пейве А.В. Избранные труды. Глубинные разломы и их роль в строении и развитии земной коры. М.: Наука, 1990. 352 с.]

Petrov O.V., 2007. Dissipative Structure of the Earth as Manifestation of Fundamental Wave Properties of the Substance. Publishing house of VSEGEI, St. Petersburg, 304 p. (in Russian) [Петров О.В. Диссипативные структуры Земли как проявление фундаментальных волновых свойств материи. СПб: ВСЕГЕИ, 2007. 304 с.].

Piotrovsky V.V., 1964. The use of morphometrics to study topography and structure of the Earth. In: The Earth in the Universe. Mysl, Moscow, p. 278-297 (in Russian) [Пиотровский В.В. Использование морфометрии для изучения рельефа и строения Земли // Земля во Вселенной. М.: Мысль, 1964. С. 278-297].

Plekhov O.A., Panteleev I.A., 2008. Optimization of deformation time prediction for solid bodies on the basis of the concept of the hierarchical nature of deformation and analysis of the history of loading. Fizicheskaya Mezomechanika 11 (6), 53 60 (in Russian) [Плехов О.А., Пантелеев И.А. Оптимизация предсказания времени разрушения твердых тел на основе представления об иерархической природе деформации и анализа истории нагружения // Физическая мезомеханика. 2008. Т. 11. № 6. С. 53-60].

Plotnikov L.M., 1985. The problem of modeling of structure formation in wave fields of mechanical stresses. In: Experimental tectonics in theoretical and applied geology. Nauka, Moscow, p. 113-117 (in Russian) [Плотников Л.М. Задача моделирования структурообразования в волновых полях механических напряжений // Экспериментальная тектоника в теоретической и прикладной геологии. М.: Наука, 1985. С. 113-117].

Ponomarev V.S., Romashov A.N., Sukhotin A.P., Tsygankov S.S., 1995. Specific features of deformation of two-layer models in modeling of geological processes. Geologiya i Geofizika 36 (4), 116-121 (in Russian) [Пономарёв В.С., Ромашов А.Н., Сухотин А.П., Цыганков С.С. Особенности разрушения двухслойных моделей при моделировании геологических процессов // Геология и геофизика. 1995. Т. 36. № 4. С. 116-121].

Rats M.V., 1962. On dependence of density of fractures from thickness of layers. Doklady AN SSSR 144 (3), $622-625$ (in Russian) [Рац М.B. К вопросу о зависимости густоты трещин от мощности слоёв // Доклады АН СССР. 1962. T. 144. № 3. C. 622-625].

Rats M.V., Chernyshov S.N., 1970. Fracturing and Properties of Fractured Rocks. Nedra, Moscow, 160 p. (in Russian) [Pau M.В., Чернышов С.Н. Трещиноватость и свойства трещиноватых горных пород. М.: Недра, 1970. 160 с.].

Rundquist D.V., Gatinsky Yu.G., Cherkasov S.V., 2004. Trans-Eurasian divider: structural and metallogenic evidences. 32IGC, Florence, Italy. Aug. 20-28. Abstracts. Part 1, 136-139. P. 620.

Sadovsky M.A., Bolkhovitinov L.G., Pisarenko V.F., 1987. Deformation of the Geophysical Medium and Seismic Process. Nauka, Moscow, 100 p. (in Russian) [Садовский М.А., Болховитинов Л.Г., Писаренко В.Ф. Деформирование геофизической среды и сейсмический процесс. М.: Наука, 1987. 100 с.].

San'kov V.A., 1989. Depths of Fault Penetration. Siberian Branch, Nauka, Novosibirsk, 136 p. (in Russian) [Саньков B.А. Глубины проникновения разломов. Новосибирск: Наука. Сибирское отделение, 1989. 136 с.].

San'kov V.A., Lukhnev A.V., Radziminovich N.A., Mel'nikova V.I., Miroshnichenko A.I., Ashurkov S.V., Calais E., Deverchere J., 2005. A Quantitative estimate of modern deformations of the Earth's crust in the Mongolian block (Based on GPS-geodesy and seismotectonic data). Doklady Earth Sciences 403 (6), 946-949.

Scholz C.H., 2002. The Mechanics of Earthguakes and Faulting. Cambridge University Press, New York, $2^{\text {nd }}$ ed., 480 p.

Seminsky K.Zh., 2001. Tectonophysical regularities of the lithosphere destruction as exemplified by the Himalayan area of compression. Tikhookeanskaya Geologiya 20 (6), 17-30 (in Russian) [Семинский К.Ж. Тектонофизические закономерности деструкции литосферы на примере Гималайской зоны сжатия // Тихоокеанская геология. 2001. Т. 20. № 6. С. 17-30].

Seminsky K.Zh., 2003. Internal Structure of Continental Fault Zones. Tectonophysical Aspect. Publishing House of SB RAS, GEO Branch, Novosibirsk, 243 p. (in Russian) [Семинский К.Ж. Внутренняя структура континентальных разломных зон. Тектонофизический аспект. Новосибирск: Издательство СО РАН. Филиал «ГЕО», 2003. 243 с.].

Seminskii K.Zh., 2008. Hierarchy in the zone-block lithospheric structure of Central and Eastern Asia. Russian Geology and Geophysics 49 (10), 771-779. http://dx.doi.org/10.1016/j.rgg.2007.11.017.

Sherman S.I., 1977. Physical Regularities of Crustal Fracturing. Nauka, Siberian Branch, Novosibirsk, 102 p. (in Russian) [Шерман С.И. Физические закономерности развития разломов земной коры. Новосибирск: Наука, 1977. 102 с.].

Sherman S.I., 1996. Destructive zones of the lithosphere, state of stress, and seismicity. In: Neotectonics and recent geodynamics of continents and oceans. RAS, MTK, Moscow, p. 157-158 (in Russian) [Шерман С.И. Деструктивные зоны литосферы, их напряженное состояние и сейсмичность // Неотектоника и современная геодинамика континентов и океанов. М.: РАН, МТК, 1996. С. 157-158].

Sherman S.I., 2002. Development of M.V. Gzovsky's concepts in recent tectonophysical studies of faulting and seismicity in the lithosphere. In: Tectonophysics today (To the anniversary of M.V. Gzovsky). UIPE RAS, Moscow, p. 49-59 (in Russian) [Шерман С.И. Развитие представлений М.В. Гзовского в современных тектонофизических исследованиях разломообразования и сейсмичности в литосфере // Тектонофизика сегодня (к юбилею М.В. Гзовского). М.: ОИФЗ РАН, 2002. С. 49-59].

Sherman S.I., 2004. Stationary and non-stationary models of formation of major faults in the lithosphere and their use for the space-time analysis of the seismic process. In: The evolution of tectonic processes in the Earth's history. Publishing House of SB RAS, GEO Branch, Novosibirsk, V. 2, p. 299-302 (in Russian) [Шерман С.И. Стационарная и нестационарная модели формирования крупных разломов литосферы и их использование для пространственно-временного анализа сейсмического процесса // Эволюция тектонических процессов в истории Земли. Новосибирск: Из- 
дательство СО РАН. Филиал «ГЕО», 2004. Т. 2. С. 299-302].

Sherman S.I., 2005. The non-stationary tectonophysical model of faults and its application to analysis of the seismic process in destructive zones of the lithosphere. Fizicheskaya Mezomechanika 8 (1), 71-80 (in Russian) [Шерман С.И. Нестационарная тектонофизическая модель разломов и ее применение для анализа сейсмического процесса в деструктивных зонах литосферы // Физическая мезомеханика. 2005. Т. 8. № 1. С. 71-80].

Sherman S.I., 2009a. A tectonophysical model of a seismic zone: experience of development based on the example of the Baikal rift system. Izvestiya, Physics of the Solid Earth 45 (11), 938-941. http://dx.doi.org/10.1134/S1069351309110 020.

Sherman S.I., 2009b. A.V. Peyve - the founder of the concept of deep faults. Geotectonics 43 (2), 100-114. http://dx.doi. org/10.1134/S0016852109020034.

Sherman S.I., Bornyakov S.A., Buddo V.Yu., 1983. Areas of Dynamic Influence of Faults (Modelling Results). Nauka, Siberian Branch of the Academy of Sciences of the USSR, Novosibirsk, 110 p. (in Russian) [Шерман С.И., Борняков С.А., Буддо В.Ю. Области динамического влияния разломов (результаты моделирования). Новосибирск: Наука, СО АН CCCP, 1983. 110 c.].

Sherman S.I., Bornyakov S.A., Cheremnykh A.V., Dzyuba I.A. et al., 2005a. Critical states of fracture systems in dissipative structures of major fault zones and diagnostics criteria. In: Modern geodynamics and hazardous natural processes in Central Asia. Institute of the Earth's Crust, Irkutsk, Issue 3, p. 267-270 (in Russian) [Шерман С.И., Борняков С.А., Черемных А.В., Дзюба И.А. и др. Критические состояния разрывных систем в диссипативных структурах зон крупных разломов и критерии их диагностики // Современная геодинамика и опасные природные процессы в Центральной Азии. Иркутск: Институт земной коры СО РАН, 2005. Вып. 3. С. 267-270].

Sherman S.I., Bornyakov S.A., Cheremnykh A.V., Dzyuba I.A., Tatarnikov A.S., 2005b. Dissipative structures in the lithosphere destruction zones (based on physical modelling results). In: Tectonics of the Earth's crust and mantle. Tectonic regularities of distribution of minerals. Inter-Agency Tectonic Commission, Moscow, V. 1, p. 65-68 (in Russian) [Шepман С.И., Борняков С.А., Черемных А.В., Дзюба И.А., Татарников А.С. Диссипативные структуры деструктивных зон литосферы (по результатам физического моделирования) // Тектоника земной коры и мантии. Тектонические закономерности размещения полезных ископаемых. М.: Межвед. тектонич. комитет., 2005. Т. 1. С. 65-68].

Sherman S.I., Cheremnykh A.A., Adamovich A.N., 1996. Fault-block divisibility of the lithosphere: Regularities of structural patterns and tectonic activity. In: Geodynamics and evolution of the Earth. UIGGM, Novosibirsk, p. 74-77 (in Russian) [Шерман С.И., Черемных А.В., Адамович А.Н. Разломно-блоковая делимость литосферы: закономерности структурной организации и тектонической активности // Геодинамика и эволюция Земли. Новосибирск: ОИГГиМ, 1996. С. 74-77].

Sherman S.I., Dem'yanovich V.M., Lysak S.V., 2004. Active faults, seismicity and fracturing in the lithosphere of the Baikal rift system. Tectonophysics 380 (3-4), 261-272. http://dx.doi.org/10.1016/j.tecto.2003.09.023.

Sherman S.I., Gladkov A.S., 1999. Fractals in studies of faulting and seismicity in the Baikal rift zone. Tectonophysics 308 (1-2), 133-142. http://dx.doi.org/10.1016/S0040-1951(99)00083-9.

Sherman S.I., Gorbunova E.A., 2008. The wave nature of fault activation in Central Asia on the basis of seismic monitoring. Fizicheskaya Mezomechanika 11 (1), 115-122 (in Russian) [Шерман С.И., Горбунова Е.А. Волновая природа активизации разломов Центральной Азии на базе сейсмического мониторинга // Физическая мезомеханика. 2008. Т. 11. № 1. С. 115-122].

Sherman S.I., Lysak S.V., Gorbunova E.A., 2012. A tectonophysical model of the Baikal seismic zone: testing and implications for medium-term earthquake prediction. Russian Geology and Geophysics 53 (4), 392-405. http://dx.doi.org/ 10.1016/j.rgg.2012.03.003.

Sherman S.I., Savitsky V.A., 2006. New data on quasi-periodical regularities in activation of fractures in real time based on monitoring of magnitudes of seismic events: case study of the Baikal rift system. Doklady Earth Sciences 408 (4), 640-644. http://dx.doi.org/10.1134/S1028334X06040295.

Sherman S.I., Seminsky K.Zh., Bornyakov S.A. et al., 1992. Faulting in the Lithosphere. Extension Zones. Siberian Branch, Nauka, Novosibirsk, 227 p. (in Russian) [Шерман С.И., Семинский К.Ж., Борняков С.А. и др. Разломообразование в литосфере // Зоны растяжения. Новосибирск: Наука. Сибирское отделение, 1992. 227 с.].

Sherman S.I., Seminsky K.Zh., Bornyakov S.A. et al., 1994. Faulting in the Lithosphere. Compression Zones. Siberian Branch, Nauka, Novosibirsk, 262 p. (in Russian) [Шерман С.И., Семинский К.Ж., Борняков С.А. и др. Разломообразование в литосфере // Зоны сжатия. Новосибирск: Наука. Сибирское отделение, 1994. 262 с.].

Sherman S.I., Seminsky K.Zh., Bornyakov S.A., Buddo V.Yu., Lobatskaya R.M., Adamovich A.N., Truskov V.A., Babichev A.A., 1991. Faulting in the Lithosphere. Strike-Slip Zone. Nauka, Siberian Branch, Novosibirsk, 261 p. (in Russian) [Шерман С.И., Семинский К.Ж. Борняков С.А., Буддо В.Ю., Лобацкая Р.М., Адамович А.Н., Трусков В.А., Бабичев А.А. Разломообразование в литосфере. Зоны сдвига. Новосибирск: Наука. Сибирское отделение, 1991. 261 с.].

Sherman S.I., Seminsky K.Zh., Cheremnykh A.V., 1999. Destructive zones and fault-block structure of Central Asia. Tikhookeanskaya Geologiya 18 (2), 41-53 (in Russian) [Шерман С.И., Семинский К.Ж., Черемных А.В. Деструктивные зоны и разломно-блоковые структуры Центральной Азии // Тихоокеанская геология. 1999. Т. 18. № 2. C. 41-53].

Sherman S.I., Seminsky K.Zh., Cheremnykh A.V., 2005c. Fault-block tectonics of Central Asia: Experiences of tectonophysical analysis. In: Actual problems of modern geodynamics of Central Asia. Publishing House of SB RAS, Novosibirsk, p. 135-165 (in Russian) [Шерман С.И., Семинский К.Ж., Черемных А.В. Разломно-блоковая тектоника Центральной Азии: опыт тектонофизического анализа // Актуальные вопросы современной геодинамики Центральной 
Азии. Новосибирск: Издательствово СО РАН, 2005. С. 135-165].

Sherman S.I., Sorokin A.P., Savitskii V.A., 2005d. New methods for the classification of seismoactive lithospheric faults based on the index of seismicity. Doklady Earth Sciences 401 (3), 413-416.

Sherman S.I., Yem N.T., Seminskii K.Zh., 2000. A new map of fault-block tectonics in Vietnam. Doklady Earth Sciences 371 (3), 473-476.

Sobolev G.A., 2002. Dynamics of faulting and seismicity. In: Tectonophysics today. UIPE RAS, Moscow, p. 67-78 (in Russian) [Соболев Г.А. Динамика разрывообразования и сейсмичность // Тектонофизика сегодня. М.: ОИФЗ РАН, 2002. C. 67-78].

Sobolev G.A., Asatryan Kh.O., 1990. Development of the hierarchy of faults during deformation of the high-plasticity material. Doklady AN SSSR 315 (2), 345-348 (in Russian) [Соболев Г.А., Асатрян Х.О. Развитие иерархии разрывов при деформировании высокопластичного материала // Доклады АН СССР. 1990. Т. 315. № 2. С. 345-348].

Sobolev G.A., Ponomarev A.V., 2003. Physics of Earthquakes and Precursors. Nauka, Moscow, 268 p. (in Russian) [Соболев Г.А., Пономарев А.В. Физика землетрясений и предвестники. М.: Наука, 2003. 268 с.].

Spivak A.A., 2011. Rigidity of the fault zones in the Earth's crust estimated from seismic data. Izvestiya, Physics of the Solid Earth 47 (7), 600-609. http://dx.doi.org/10.1134/S1069351311060061.

Spivak A.A., Spungin V.G., 1998. Determination of active stresses and specific features of deformation of block mediums on the basis of geological medium microvibration records. Geoekologiya 4, 71-81 (in Russian) [Спивак А.А., Спунгин В.Г. Определение действующих напряжений и особенностей деформирования блочных сред на основе регистрации микроколебаний геологической среды // Геоэкология. 1998. № 4. С. 71-81].

Spivak A.A., Tsvetkov V.M., 2009. A new model of the zonal structure of fractures. Doklady Earth Sciences 424 (1), 151-154. http://dx.doi.org/10.1134/S1028334X09010322.

Stepashko A.A., 2011. Seismodynamics and deep internal origin of the North China zone of strong earthquakes. Geodynamics \& Tectonophysics 2 (4), 341-355. http://dx.doi.org/10.5800/GT-2011-2-4-0049.

Suvorov A.I., 1977a. Fractures and Horizontal Movements of Mountain Structures of the USSR. Nauka, Moscow, 135 p. (in Russian) [Суворов А.И. Разломы и горизонтальные движения горных сооружений СССР. М.: Наука, 1977а. 135 с.].

Suvorov A.I., 1977b. Fractures and Horizontal Movements of Platform Areas of the USSR. Nauka, Moscow, 143 p. (in Russian) [Суворов А.И. Разломы и горизонтальные движения платформенных областей СССР. М.: Наука, $1977 б$. 143 c.].

Trifonov V.G., 1985. Specific features of development of active faults. Geotektonika 2, 16-26 (in Russian) [Трифонов В.Г. Особенности развития активных разломов // Геотектоника. 1985. № 2. С. 16-26].

Ulomov V.I., 1993. Waves of seismogeodynamic activation and long-term prediction of earthquakes. Fizika Zemli 4, 43-53 (in Russian) [Уломов В.И. Волны сейсмогеодинамической активизации и долгосрочный прогноз землетрясений // Физика Земли. 1993. № 4. С. 43-53].

Vashchilov Yu.Ya., 1984. The Block-Layered Model of the Earth’s Crust and Upper Mantle. Nauka, Moscow, 238 p. (in Russian) [Ващилов Ю.Я. Блоково-слоистая модель земной коры и верхней мантии. М.: Наука, 1984. 238 с.].

Xu X., Deng Q., 1996. Nonlinear characteristics of paleoseismicity in China. Journal of Geophysical Research 101 (B3), 6209-6231. http://dx.doi.org/10.1029/95JB01238.

Zhang Y., Ma Y., Yang D., 2003. Neotectonic activity of the southern marginal fault zone of the Taihangshan Mountains and its regional kinematic implications. Seismology and Geology 25 (2), 169-182.

Zhurkov S.N., Kuksenko V.S., Petrov V.A., 1983. Is it possible to predict the destruction? In: The future of science. Znanie, Moscow, p. 99-107 (in Russian) [Журков С.Н., Куксенко В.С., Петров В.А. Можно ли прогнозировать разрушение? // Будущее науки. М.: Знание, 1983. С. 99-107].

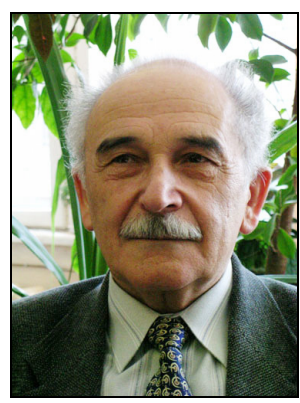

Шерман Семен Иойнович, академик Российской академии естественных наук, докт. геол.-мин. наук, профессор, г.н.с.

Институт земной коры СО РАН

664033, Иркутск, ул. Лермонтова, 128, Россия

Тел.: (3952)428261; e-mail: ssherman@crust.irk.ru

Sherman, Semen I., Academician of the Russian Academy of Natural Sciences,

Doctor of Geology and Mineralogy, Professor, Chief Researcher

Institute of the Earth's Crust, SB RAS

128 Lermontov street, Irkutsk 664033, Russia

Tel.: (3952)428261; e-mail: ssherman@crust.irk.ru 